\title{
Early fossils illuminate character evolution and interrelationships of Lampridiformes (Teleostei, Acanthomorpha)
}

\author{
DONALD DAVESNE ${ }^{1,2 *}$, MATT FRIEDMAN ${ }^{3}$, VERONIQUE BARRIEL $^{1}$, \\ GUILLAUME LECOINTRE ${ }^{2}$, PHILIPPE JANVIER ${ }^{1}$, CYRIL GALLUT $^{2}$ and \\ OLGA OTERO $^{4}$
}

${ }^{1}$ Centre de Recherche sur la Paléobiodiversité et les Paléoenvironnements, UMR 7207 CNRS-

MNHN-UPMC, Muséum national d'Histoire naturelle, CP 38, 57 rue Cuvier, F-75005, Paris,

France

${ }^{2}$ Institut de Systématique, Évolution, Biodiversité, UMR 7205 CNRS-MNHN-UPMC-EPHE, Muséum national d'Histoire naturelle, CP 26, 57 rue Cuvier, F-75005, Paris, France

${ }^{3}$ Department of Earth Sciences, University of Oxford, South Parks Road, Oxford OX1 3AN, $U K$

${ }^{4}$ Institut International de Paléoprimatologie, Paléontologie Humaine: Évolution et Paléoenvironnements, UMR 6046, Faculté des Sciences Fondamentales et Appliquées, Université de Poitiers, 40 av. du Recteur Pineau, F-86 022 Poitiers cedex, France

*Corresponding author. E-mail: donald.davesne@edu.mnhn.fr

Running title: FOSSILS AND LAMPRIDIFORMES INTERRELATIONSHIPS 


\begin{abstract}
Lampridiformes is a peculiar clade of pelagic marine acanthomorph (spiny-rayed) teleosts. Its phylogenetic position remains ambiguous, and varies depending on the type of data (morphological or molecular) used to infer interrelationships. Because the extreme morphological specializations of lampridiforms may have overwritten the ancestral features of the group with a bearing on its relationships, the inclusion of fossils that exhibit primitive character state combinations for the group as a whole is vital in establishing its phylogenetic position. Therefore, we present an osteological dataset of extant (ten taxa) and fossil (14 taxa) acanthomorphs, including early Late Cretaceous taxa for which a close relationship with extant Lampridiformes has been suggested: $\uparrow$ Aipichthyoidea, $\uparrow$ Pharmacichthyidae and $\dagger$ Pycnosteroididae. We find that all three taxa plus Lampridiformes form a clade that we call Lampridomorpha. Under this hypothesis, $\uparrow$ Aipichthyoidea is paraphyletic. The inclusion of fossils in the analysis changes the topology, highlighting their critical importance in phylogenetic studies of morphological characters. When fossils are included, Lampridomorpha is sister to Euacanthomorpha (all other extant acanthomorphs), concurring with most previous anatomical studies, but conflicting with most molecular results. Lampridomorpha as a whole was a major component of the earliest acanthomorph faunas, notably in the Cenomanian.
\end{abstract}

ADDITIONAL KEYWORDS: $\uparrow$ Aipichthyoidea - Cretaceous - cladistics - Lampridomorpha $-\uparrow$ Pharmacichthyidae $-\uparrow$ Pycnosteroididae 


\section{INTRODUCTION}

Lampridiformes is a peculiar clade of teleosts, strictly marine and pelagic, present in every ocean of the world. Extant lampridiform richness is relatively low, with about 20 species and 11 genera grouped in six families (Olney, 1984; Nelson, 2006; Roberts, 2012): Veliferidae (velifers), Lamprididae (opahs), Lophotidae (crestfishes), Radiicephalidae (tapertail), Trachipteridae (ribbonfishes) and Regalecidae (oarfishes). Stylephoridae (tubeeye) has been recently excluded from Lampridiformes by congruent molecular and morphological data (Miya et al., 2007; Grande, Borden, \& Smith, 2013). Contrasting with their low specific diversity, lampridiforms exhibit remarkable morphological disparity: from the small, deep-bodied velifers to the very large, ribbon-like oarfish. Deep-bodied forms (veliferids and lampridids) are referred to as "bathysomes", while ribbon-like taxa (lophotids, radiicephalids, trachipterids and regalecids) compose the taeniosomes (Regan, 1907; Olney, Johnson, \& Baldwin, 1993; Wiley, Johnson, \& Dimmick, 1998).

Lampridiformes have historically been difficult to classify amongst teleosts. Early works based on anatomy placed them in Acanthomorpha (spiny-rayed teleosts) and Acanthopterygii, close to or within the "perciforms" (e.g. Regan, 1907; Greenwood et al., 1966). More recently, most morphological studies placed Lampridiformes as sister to Euacanthomorpha - that is, sister to all other acanthomorphs (Johnson \& Patterson, 1993; Olney et al., 1993; Wiley et al., 1998; Wiley, Johnson, \& Dimmick, 2000) - yet this view has been contested by some (Wu \& Shen, 2004). Molecular studies are even more equivocal and suggested varying positions for Lampridiformes: sister to Euacanthomorpha (Wiley et al., 1998, 2000; Smith \& Wheeler, 2006; Grande et al., 2013 with parsimony), to Polymixiiformes + Paracanthopterygii (Dettaï \& Lecointre, 2005), to Polymixiiformes alone (Li et al., 2009), to Percopsiformes (Dettaï \& Lecointre, 2008; Li et al., 2009), to Paracanthopterygii (Betancur-R. et al., 2013a) and to Euacanthopterygii (Near et al., 2012, 2013; Grande et al., 2013 with maximum likelihood; Faircloth et al., 2013). Molecular studies based on mitochondrial DNA suggested that Lampridiformes are sister to the nonacanthomorph Ateleopodiformes (Miya, Kawaguchi, \& Nishida, 2001; Miya et al., 2003) or Myctophiformes (Miya, Satoh, \& Nishida, 2005; Miya et al., 2007; Poulsen et al., 2013), thus implying acanthomorph polyphyly.

Anatomically, Lampridiformes are very specialized, with their highly protractile jaws and peculiar fins with poorly developed spines (Oelschläger, 1976, 1983; Olney et al., 1993). Due to their distinctive anatomy, Lampridiformes are difficult to relate to other acanthomorph 
subgroups. This difficulty in formalizing hypotheses of homology between lampridiforms and other acanthomorphs explains, in part, the uncertainty arising from morphological studies, and difficulty in assessing the results of molecular analyses in the light of anatomical data. The discovery of fossil relatives of lampridiforms might therefore be especially helpful in identifying plesiomorphic conditions with a bearing on the phylogenetic affinities of the clade. Twelve entirely fossil genera of Lampridiformes have been described (for reviews, see Bannikov, 1999; Carnevale, 2004). They have been referred to crown-group Lampridiformes, as they present most of the anatomical specialisations of extant representatives (Bannikov, 1990, 1999; Sorbini \& Sorbini, 1999). As such, these fossils do not bear very distinctive character state combinations that would inform us on the position of the group among Acanthomorpha.

Conversely, other fossil taxa might potentially be informative for the large scale relationships of Lampridiformes. These include several extinct acanthomorph groups that have been described from early Late Cretaceous outcrops in the Near East, England, Slovenia, Mexico, Morocco, and Italy. Most of them are coeval with the oldest known fossil Acanthomorpha, which are Cenomanian in age (93-100 Myr). In contrast, the oldest unequivocal lampridiform is the Campanian-Maastrichtian (70-83 Myr ago): $\uparrow$ Nardovelifer altipinnis Sorbini \& Sorbini, 1999, which has been interpreted as a close relative of modern veliferids. These extinct Cretaceous taxa are interesting in the context of lampridiform interrelationships for two reasons. First, they show mosaic character combinations that are not found in modern taxa, suggesting that they can add valuable information if included in a phylogenetic analysis of acanthomorphs. Second, they have been repeatedly nominated as potential sister-groups to Lampridiformes, although their phylogenetic position remains largely untested.

In this paper, we assess the phylogenetic position of Lampridiformes by including Acanthomorpha and closely related outgroup taxa - notably the Late Cretaceous fossil candidates as sister-groups of Lampridiformes - for the first time in the same phylogenetic analysis of morphological characters.

\section{POTENTIAL CRETACEOUS RELATIVES OF LAMPRIDIFORMES}

Five extinct taxa have been proposed as potential sister groups to lampridiforms: $\uparrow$ Araripichthyidae, $\uparrow$ Dinopterygidae, $\uparrow$ Pycnosteroididae, $\uparrow$ Pharmacichthyidae and $\dagger$ Aipichthyoidea. 
$\uparrow$ Araripichthyidae is a monogeneric family comprising four species (Alvarado-Ortega \& Brito, 2011): $\uparrow$ Araripichthys castilhoi Silva Santos, 1985 from the Albian of Brazil and Mexico; $\uparrow$ A. corythophorus Cavin, 1997 from the Turonian of Morocco; $\uparrow$ A. axelrodi Maisey $\&$ Moody, 2001 from the Aptian of Venezuela; and $\dagger$ A. weberi Alvarado-Ortega \& Brito, 2011 from the Albian of Mexico. A close relationship between $\uparrow$ Araripichthys and lampridiforms has been suggested by Maisey \& Blum (1991: 215), because this genus shows a large ascending process on the premaxilla and absence of pelvic fins (a character present in only some taeniosomes); however, Maisey \& Moody (2001) later argued that these features are probably convergent with lampridiforms, because $\uparrow$ Araripichthys lacks most acanthomorph, ctenosquamate, and even euteleost synapomorphies. Cavin (2001) performed a phylogenetic analysis showing that $\uparrow$ Araripichthys is closer to the non-acanthomorph euteleost Esox than to the acanthomorph $\dagger$ Hoplopteryx.

The four remaining taxa, $\uparrow$ Dinopterygidae, $\uparrow$ Pycnosteroididae, $\uparrow$ Pharmacichthyidae and $\uparrow$ Aipichthyoidea were grouped together by Patterson (1964) in the $\uparrow$ Dinopterygoidei. In his review of Cretaceous acanthomorphs, he mentioned a possible relationship between lampridiforms and †dinopterygoids (1964: 473), an opinion strengthened by his subsequent work on the caudal skeleton (1968: 97). Oelschläger (1983: fig. 108) concurred with this opinion in his review of lampridiform anatomy. Patterson (1993: 36) later explained that his $\dagger$ Dinopterygoidei was most probably a non-monophyletic assemblage, lacking unique synapomorphies. We agree with Patterson's assessment, and will therefore treat the component groups of $\uparrow$ Dinopterygoidei separately.

$\dagger$ Dinopterygidae consists of only one species, $†$ Dinopteryx spinosus (Davis, 1887), from the Santonian of Sahel Alma, Lebanon. Little is known about this taxon, due to the poor preservation of the few specimens available, and Patterson (1993: 42) chose to consider it as an acanthomorph incertae sedis.

$\dagger$ Pycnosteroididae is represented by two species: $†$ Pycnosteroides levispinosus (Hay, 1903) from the Cenomanian of Hajula, Lebanon and $\uparrow$ Magrebichthys nelsoni Murray \& Wilson, 2014 from the Cenomanian-Turonian of Agoult, Morocco. $†$ Pycnosteroides has been well-described based on complete specimens, notably by Gayet (1980a), who considered this genus related to modern holocentrids (Gayet, 1982). Patterson (1993: 40) maintained the genus as Acanthomorpha incertae sedis. Murray \& Wilson (2014) suggested that the whole family is part of the order Polymixiiformes, by finding $\uparrow$ Magrebichthys in a polytomy with Polymixia and paracanthopterygians. 
There are three species of $\uparrow$ Pharmacichthyidae: $\uparrow$ Pharmacichthys venenifer Smith Woodward, 1942, $\uparrow P$. numismalis Gayet, 1980a, both from the Cenomanian of Hakel, Lebanon, and $\uparrow P$. judensis Gayet, 1980b from the Cenomanian of Ein Yabrud, Palestine. Gayet (1980a,b,c) argued that $\dagger$ Pharmacichthys is not even an acanthomorph, whereas Rosen \& Patterson (1969) and Patterson (1993) listed it amongst possible lampridiform relatives.

The super-family $\dagger$ Aipichthyoidea is a more diverse group, with 13 species included in eight genera and two families (Otero \& Gayet, 1996; Alvarado-Ortega \& Than-Marchese, 2012; Murray \& Wilson, 2014). Family †Aipichthyidae includes $\uparrow$ Aipichthys [five species: $\uparrow A$. nuchalis (Dixon, 1850), $\uparrow A$. minor (Pictet, 1850), $\uparrow A$. pretiosus Steindachner, 1860, $\uparrow A$. velifer Smith Woodward, 1901 and $\uparrow$ A. oblongus Gayet, 1980a], $\uparrow$ Paraipichthys lusitanicus Gaudant, 1978 and $\uparrow$ Freigichthys elleipsis Otero, 1997. Family $\dagger$ Aipichthyoididae includes $\uparrow$ Aipichthyoides formosus Gayet, 1980b, $\uparrow$ A. galeatus Gayet, 1980b, $\uparrow$ Aspesaipichthys cavaensis Taverne, 2004 and $\dagger$ Zoqueichthys carolinae Alvarado-Ortega \& Than-Marchese, 2012. $\dagger$ Errachidia pentaspinosa Murray \& Wilson, 2014 and $\dagger$ Homalopagus multispinosus Murray \& Wilson, 2014 are two species with family incertae sedis. $\uparrow$ Aipichthyoidea has a large geographical distribution: $\uparrow$ Aipichthyoides and $\uparrow$ Freigichthys are restricted to the East Mediterranean (Gayet, 1980b; Otero, 1997), but the five species of $\uparrow$ Aipichthys are known from Lebanon, England and Slovenia (Patterson, 1964; Radovčić, 1975; Gayet, 1980a), $\uparrow$ Aspesaipichthys is from Italy (Taverne, 2004), $\uparrow$ Paraipichthys from Portugal (Gaudant, 1978), †Zoqueichthys from Mexico (Alvarado-Ortega \& Than-Marchese, 2012) and finally $\dagger$ Errachidia and $\dagger$ Homalopagus are from Morocco (Murray \& Wilson, 2014). All of these genera are Cenomanian (or Cenomanian-Turonian) of age, with the exception of $\uparrow$ Aspesaipichthys which is younger (Campanian-Maastrichtian). Although Patterson (1964, 1993), Rosen \& Patterson (1969) and Oelschläger (1983) suggested that †aipichthyids were related to lampridiforms, Gayet (1980a,b) proposed that they were closer to paracanthopterygians. Finally, Otero \& Gayet $(1995,1996)$ placed †aipichthyoids as sister to Euacanthomorpha (see below), but not without mentioning a possible lampridiform affinity (1995: 223).

Few phylogenetic studies included these Cretaceous taxa. The first was presented by Otero \& Gayet $(1995,1996)$, including only †aipichthyoids among our candidate taxa. They found that the superfamily is monophyletic and composed of two sister-groups: $\uparrow$ Aipichthyidae ( $\uparrow$ Aipichthys and $\uparrow$ Paraipichthys) and $\uparrow$ Aipichthyoididae ( $†$ Aipichthyoides). Their analysis also retrieved $\dagger$ Aipichthyoidea as a sister-group to Euacanthomorpha, but lampridiforms were not included in the study. Alvarado-Ortega \& Than-Marchese (2012), 
then Murray \& Wilson (2014) re-analysed Otero \& Gayet's matrix, adding new taxa. They included $\dagger$ Freigichthys in $\dagger$ Aipichthyidae and $\uparrow$ Aspesaipichthys and $\uparrow$ Zoqueichthys in $\dagger$ Aipichthyoididae. Their results did not change the position of †aipichthyoids amongst Acanthomorpha, and lampridiforms were once again unrepresented in the data matrix. Thus, despite the fact that a relationship between Lampridiformes and - at least - faipichthyoids had been repeatedly proposed in the literature before, all previous studies were unable to test this hypothesized relationship.

\section{MATERIAL AND METHODS}

\section{TAXONOMIC SAMPLING}

Our data matrix includes 24 taxa. The 14 fossil taxa are early Late Cretaceous in age, and they include $\uparrow$ Ctenothrissa sp. (outgroup), the three species of $\uparrow$ Pharmacichthys $(\dagger P$. judensis, $\uparrow P$. numismalis, $\uparrow P$. venenifer $), \uparrow P y c n o s t e r o i d e s ~ l e v i s p i n o s u s$, eight species from six different genera of $\uparrow$ Aipichthyoidea ( $\dagger$ Aipichthys minor, $\uparrow$ A. oblongus, $\uparrow$ A. velifer, $\uparrow$ Paraipichthys lusitanicus, $\uparrow$ Freigichthys elleipsis, $\uparrow$ Aipichthyoides galeatus, $\uparrow$ Aspesaipichthys cavaensis, $\dagger$ Zoqueichthys carolinae) and $\dagger$ Sphenocephalus fissicaudus Agassiz, 1838, one the oldest known paracanthopterygian, known by well-preserved specimens (Rosen \& Patterson, 1969; but see Newbrey et al., 2013). We chose not to include $\dagger$ Araripichthys, judging that Maisey \& Moody (2001) and Cavin (2001) provided convincing evidence that this genus is not an acanthomorph. $\dagger$ Dinoptery $x$ was also excluded, because the incompleteness of the available material made most relevant characters impossible to assess (Patterson, 1993).

The ten extant taxa were chosen from all major acanthomorph clades and closely related non-acanthomorphs. These include: the aulopiform Synodus intermedius (Spix \& Agassiz, 1829) and the myctophiform Gymnoscopelus sp. as non-acanthomorph outgroups; the holocentrid Myripristis sp. for Euacanthopterygii; Polymixia nobilis Lowe, 1836 for Polymixiiformes; the percopsiform Aphredoderus sayanus (Gilliams, 1824) and the gadiform Merluccius merluccius (Linnaeus, 1758) for Paracanthopterygii; the veliferid Metavelifer multiradiatus (Regan, 1907), the lampridid Lampris spp. and the taeniosomes Regalecus glesne Ascanius, 1772 and Trachipterus spp. for Lampridiformes.

This sampling makes the present study the first to simultaneously include representatives from all extant acanthomorph subgroups (Lampridiformes and Euacanthopterygii were absent from Otero \& Gayet, 1996) and Cretaceous fossils. This is also 
the first time the placements of $\dagger$ Pharmacichthys and $\dagger$ Pycnosteroides have been assessed in a phylogenetic analysis.

The list of specimens examined is available in Table 1. Extant specimens are dry osteological preparations, unless otherwise stated. Taxa not included in Table 1 were coded exclusively from the literature.

\section{PHYLOGENETIC ANALYSES}

The character matrix was analysed using PAUP 4.0 (Swofford, 2001). All characters were unordered and assigned an equal weight of one, because we had no arguments on character ordering and polarity prior to the analyses.

We performed two consecutive phylogenetic analyses. Analysis 1 included the extant taxa only (ten taxa), with trees rooted with one of the outgroups (Synodus). We used the Exhaustive search algorithm for this analysis. Analysis 2 included all 24 taxa (fossil and extant), with trees still rooted with Synodus. Because 24 taxa exceed the capability of exhaustive algorithms, we used the Branch-and-Bound search algorithm in this analysis, with "furthest" addition sequence. Character polarity was determined a posteriori by the outgroup criterion.

Tree descriptions were computed in PAUP 3.1.1 (Swofford \& Begle, 1993), for an accurate reconstruction of character states. We calculated the Bremer indexes automatically using a PAUP script generated with TreeRot v.2 (Sorenson, 1999).

\section{RESULTS \\ CHARACTERS}

The 39 skeletal characters used by Otero \& Gayet $(1995,1996)$, and then by AlvaradoOrtega \& Than-Marchese (2012) for aipichthyoid phylogeny were coded in our matrix. We also included 14 skeletal characters described by Olney et al. (1993) in their study of lampridiform intrarelationships, that are applicable in fossils. The characters that we used come from every region of the skeleton: cranial (Fig. 1), vertebral, dorsal (Fig. 2) and anal fins, caudal (Fig. 3) and appendicular skeleton (Fig. 4). In total, 67 characters have been coded; they are detailed in Table 2.

Characters 29, 43 and 64 are new, and they are described below. For description of the remaining characters, please refer to the appropriate references in Table 2. 


\section{Character 29:}

Urohyal: $0=$ not expanded ventrally; $1=$ expanded by a large ventral lamina

The urohyal is a median unpaired membrane bone surrounded laterally by the gill arches and the branchiostegal rays (Fig. 1G-H). In lampridiforms, the ventral edge of the urohyal forms an extensive lamina (Fig. 1H, 4C), which is absent in most other acanthomorphs (Fig. 1G).

\section{Character 43:}

First soft ray of the dorsal fin elongated and unbranched: $0=$ absent; $1=$ present

The soft rays of the dorsal fin (posterior to the fin spines when they are present) are branched distally in most teleosts. In $\uparrow$ aipichthyoids, $\uparrow$ Pharmacichthys and lampridiforms, the first soft ray is unbranched and elongated when compared to the other dorsal soft rays.

\section{Character 64:}

Internal wings of the pelvic bone: $0=$ separated; $1=$ joined medially

Usually in acanthomorphs (Fig. 4D) and close relatives, both pelvic bones only contact each other at the level of their median processes (Stiassny \& Moore, 1992: figs 2, 3). In $\dagger$ Freigichthys, $\dagger$ Zoqueichthys (Fig. 4E), lampridiforms (Fig. 4F) and most euacanthopterygians, the internal wings of the pelvic bones are expanded and make extensive contact with each other on a median line.

The complete data matrix (24 taxa, ten extant and 14 fossil; 67 characters) is available in Table 3. There is $11 \%$ missing data, noted as '?' in the matrix: this is mainly a result of incomplete fossils, but is also linked with extant Lampridiformes for characters 9, 14, and 15, because of the bad state of preservation of the collection material that we accessed. As a result of the chosen coding strategy, $2 \%$ of the character states are treated as inapplicable. They are noted '-' in the matrix. Only one character, character 18 , is uninformative.

\section{PHYLOGENETIC RESULTS}

Analysis 1 (extant taxa only) yielded one parsimonious tree, with a tree length of 107 steps, a consistency index (CI) of 0.64, and a retention index (RI) of 0.71 (Fig. 5). Within the monophyletic Acanthomorpha, it places Lampridiformes sister to Paracanthopterygii (Gadiformes + Percopsiformes). This relationship is well-supported by seven unambiguous synapomorphies (see below). 
Analysis 2 yielded 12 parsimonious trees of 155 steps in length, $\mathrm{CI}=0.48$ and $\mathrm{RI}=$ 0.72. These multiple most parsimonious trees largely reflect uncertain relationships within the genera $\uparrow$ Aipichthys and $\uparrow$ Pharmacichthys. The strict consensus is shown in Figure 6.

This analysis supports monophyly of Euacanthomorpha, with Polymixia sister to a clade formed by Euacanthopterygii (Myripristis) and Paracanthopterygii (including $\dagger$ Sphenocephalus). Sister to Euacanthomorpha is a clade including all †Aipichthyoidea, $\dagger$ Pharmacichthyidae and $\dagger$ Pycnosteroides, together with Lampridiformes (clade A). If fossils are not considered, Lampridiformes is therefore sister to Euacanthomorpha. Clade A is supported by eight unambiguous characters.

Within clade A, $\uparrow$ Paraipichthys, $\uparrow$ Aipichthys, $\uparrow$ Freigichthys, $\uparrow$ Pycnosteroides and $\uparrow$ Pharmacichthys form clade B. $\uparrow$ Paraipichthys is sister to all the other genera. $\dagger$ Aipichthys and $\uparrow$ Freigichthys on one hand, $\uparrow$ Pycnosteroides and $\uparrow$ Pharmacichthys on the other form subclades.

A well-supported clade (clade C) groups together $\uparrow$ Aipichthyoididae (sensu AlvaradoOrtega \& Than-Marchese, 2012) and Lampridiformes, with $\uparrow$ Aipichthyoides and $\dagger$ Aspesaipichthys closer to Lampridiformes (clade D) than to †Zoqueichthys.

In both analyses, Lampridiformes is monophyletic and supported by 12 (analysis 1) and ten (analysis 2) unambiguous synapomorphies, respectively. Our results are consistent with the previous morphological and molecular hypotheses of lampridiform intrarelationships (e.g. Olney et al., 1993; Wiley et al., 1998): veliferids (exemplified by Metavelifer) are sister to a clade composed by Lampris and taeniosomes (represented here by Trachipterus and Regalecus).

The complete list of character state changes is given in the Appendix. If inference for a character change on the parsimonious tree (or the strict consensus tree) provided several character distributions (resulting in an ambiguous state for some nodes), every possible optimization was considered before one was selected based on biological considerations.

\section{DISCUSSION}

\section{TOPOLOGICAL IMPACT OF THE INCLUSION OF FOSSILS}

The impact of fossils in phylogenetic reconstruction has been debated ever since the generalisation of cladistic methodology. Following claims that fossil taxa have little impact in topologies (e.g. Patterson, 1981), empirical studies have shown that all available taxa (extant and fossils) should be included in an analysis so that it can reflect most closely the 
interrelationships of characters and taxa (Gauthier, Kluge, \& Rowe, 1988; Donoghue et al., 1989; Cobbett, Wilkinson, \& Wills, 2007). Within acanthomorphs, studies have explored the importance of fossils for reconstructing the evolutionary acquisition of complex characters (e.g. Friedman, 2008; Friedman et al., 2013), studying the sequence of character acquisition (e.g. Murray \& Wilson, 1999) and influencing the topology, even when they are incomplete (e.g. Santini \& Tyler, 2004).

The case of Lampridiformes is particularly interesting, because no enduring consensus has been reached on their phylogenetic position among acanthomorphs (see "Introduction"). This is especially true with datasets composed of nuclear genes that, in addition, consistently show low support values for the immediately more inclusive clade: for example $54 \%$ of bootstrap replicates in Betancur-R. et al. (2013a) and less than 70\% in Near et al. (2013). Yet, under a certain threshold (for example, 95\% according to Felsenstein, 1985), nodes should in principle be considered as statistically non-significant. New molecular studies, specifically sampling the base of the acanthomorph tree, are needed in order to better understand the source of these low nodal supports and conflicting topologies. In this context, assessing how taxonomic sampling impacts the reconstructions of topology and character evolution is particularly relevant, especially with fossils, which are absent from molecular datasets.

With the present study, we show another empirical case where fossils have a direct impact on a topology including numerous extant taxa. The phylogenetic position of Lampridiformes varies between our two analyses, which otherwise are based on identical datasets.

When only extant taxa are included (analysis 1), Lampridiformes is sister to Paracanthopterygii (Fig. 5), a position that has already been suggested by some molecular studies (e.g. Betancur-R. et al., 2013a), but by no other morphological analyses to date. The Lampridiformes + Paracanthopterygii clade is then supported by at least seven synapomorphies: the loss of the antorbital (character $7,0 \rightarrow 1$ ), the loss of postabdominal epineurals (character $36,0 \rightarrow 1$ ), the presence of only one supraneural (character $38,0 \rightarrow 2$ ), the fusion of the upper hypurals together (character 52,0 $\rightarrow 1$ ) and with the second ural centrum (character 53, $0 \rightarrow 1$ ), the fusion of the lower hypurals (character 54, $0 \rightarrow 1$ ) and the fusion of the postcleithra (character $61,0 \rightarrow 1$ ).

The inclusion of fossils in analysis 2 (Fig. 6) changes the position of Lampridiformes relative to other extant taxa: their extant sister-group becomes Euacanthomorpha. Support for this hypothesis is also high, with at least five euacanthomorph synapomorphies (see "Taxonomy and character evolution" below). 
Such incongruence between the results of both analyses means that at least one of the topologies is misleading and should be rejected, as well as the hypotheses of secondary homology it implies. All synapomorphies that support the Lampridiformes + Paracanthopterygii clade after analysis 1 are linked to reduction or fusion of bones (see above), characters for which primary homology hypotheses are difficult to formalize and which are known to have occurred independently in many different acanthomorph groups. In analysis 2, homology for these character states in Lampridiformes and Paracanthopterygii is rejected by the inclusion of additional data: new character state distributions from fossils. Thus, convergent appearance of the features in both clades is implied by analysis 2 . Previously, the absence of the fossil taxa mistakenly supported a relationship between these two clades that show a high amount of character transformation (especially reduction), in a way similar to so-called long-branch attraction in molecular phylogenetics.

The result of analysis 2 (including fossils) shows congruence with previous morphological (Johnson \& Patterson, 1993; Wiley et al., 2000) as well as molecular analyses (Wiley et al., 2000; Smith \& Wheeler, 2006; Grande et al., 2013 with parsimony).However, it contradicts other molecular results. For instance, the monophyly of Acanthomorpha (including Lampridiformes) is recovered unambiguously, in contrast with phylogenies based on the mitogenome (Miya et al., 2001, 2003, 2005; Poulsen et al., 2013). Other large-scale molecular studies using diverse markers and methods proposed a LampridiformesEuacanthopterygii clade (Near et al., 2012, 2013; Faircloth et al., 2013), which is not supported by our data. Should this alternative molecular hypothesis be confirmed by future studies, however, some lampridomorph characters are also found in euacanthopterygians and could be taken as potential evidence of a relationship between both clades. These include the anatomy of the pelvic skeleton (with the pelvic bones joined medially by their internal wings) and the presence of a pelvic spine in several taxa.

\section{TAXONOMY AND CHARACTER EVOLUTION}

Works such as Johnson \& Patterson (1993), Olney et al. (1993) or Otero \& Gayet (1996) established a framework for large-scale acanthomorph classification. Once we established that our second analysis (Fig. 6), including both extant Lampridiformes and Cretaceous fossils, efficiently sorted out homology and homoplasy in our character set, we were able to bring forth some new taxonomic hypotheses and confirm some others.

The classification of acanthomorphs we propose is as follows: 
TELEOSTEI MÜLLER, 1846

NEOTELEOSTEI NELSON, 1969

EURYPTERYGII ROSEN, 1973

Ctenosquamata Rosen, 1973

ACANTHOMORPHA ROSEN, 1973

Included taxa: Euacanthomorpha (see below); Lampridomorpha (see below).

Eight unambiguous character states support Acanthomorpha.

1. Frontal branch of the sensory canal running through the frontal and pterotic in a groove (character 14, $0 \rightarrow 1$ ).

In non-acanthomorph teleosts, this canal is enclosed within a bony tube. There is a reversal of this character state, at least in $\dagger$ Pharmacichthys numismalis.

2. Developed sagittal crest (character 16, $0 \rightarrow 1$ ).

The sagittal crest primitively consists of the supraoccipital alone. It is secondarily reduced in taeniosome lampridiforms (exemplified by Trachipterus and Regalecus).

3. Dorsal limb of the posttemporal firmly bound to the epiotic (character $22,0 \rightarrow 1$ ).

This acanthomorph synapomorphy has been proposed first by Stiassny (1986).

4. Spines in the dorsal fin (character $42,0 \rightarrow 1$ ).

They are secondarily lost in Merluccius and all lampridiforms, except veliferids.

5. Hemaxanal complex (character 46, $0 \rightarrow 1$ ).

This fusion of the anterior-most anal pterygiophores is secondarily lost in Merluccius and most lampridiforms.

6. Spines in the anal fin (character $47,0 \rightarrow 1$ ).

In several acanthomorph groups not included in the analysis (such as batrachoidiforms and nototheniids), spines are present in the dorsal fin only. This suggests that the presence of spines in the anal and dorsal fins is not phylogenetically linked and should be treated as two independent characters. This contradicts character 6 from Otero \& Gayet (1996). Like the dorsal fin ones, anal fin spines are lost in Merluccius and lampridiforms excluding veliferids.

7. Loss of the urodermals (character $56,0 \rightarrow 1$ ).

8. Loss of the dermal caudal scutes (character $57,0 \rightarrow 1$ ).

Seven out of ten acanthomorph characters from Otero \& Gayet (1996) are recovered here as acanthomorph synapomorphies. Their character 5 (neural spines fused to their centra) 
- which is our character $33(0 \rightarrow 1)$ - is interpreted as a ctenosquamate synapomorphy instead. Their character 10 (reduction of the number of pelvic fin rays to seven, character $66,0 \rightarrow 1$ ) is recovered as independently derived in euacanthomorphs (see below), $\uparrow$ Aipichthyoides and Clade B (see below). Optimization of their character 3 (our character 15, $0 \rightarrow 1$ ) is ambiguous: it could also be a euacanthomorph synapomorphy.

\section{EUACANTHOMORPHA JOHNSON \& PATTERSON, 1993}

Included taxa: Polymixiiformes (represented by Polymixia); Euacanthopterygii (represented by Myripristis); Paracanthopterygii (represented by $\dagger$ Sphenocephalus, Aphredoderus and Merluccius).

Five character states are unambiguously found to support a clade which includes Polymixia, Myripristis, $\uparrow$ Sphenocephalus, Aphredoderus and Merluccius, to the exclusion of extant lampridiforms. This clade matches the one named Euacanthomorpha by Johnson \& Patterson (1993).

1. Postmaxillary process of the premaxilla (character $1,0 \rightarrow 1$ ).

A posterior notch appears on this process in paracanthopterygians.

2. Spina occipitalis (character $23,0 \rightarrow 1$ ).

This character was interpreted as an acanthomorph synapomorphy by Stiassny (1986), who described it first.

3. Foramen in the distal ceratohyal (character $27,1 \rightarrow 0$ ).

A so-called "beryciform" foramen is also present in $\uparrow$ Ctenothrissa, $\uparrow$ Pycnosteroides, $\dagger$ Pharmacichthys and in veliferid lampridiforms. It is secondarily lost in extant paracanthopterygians.

4. Anterior epineurals originating on vertebral centra or transverse processes (character 35, $0 \rightarrow 1)$.

The state appears convergently in $\uparrow$ Pharmacichthys and $\dagger$ Pycnosteroides.

5. Seven pelvic soft rays or less (character $66,1 \rightarrow 0$ ).

This character is interpreted as an acanthomorph synapomorphy by Otero \& Gayet (1996, character 10).

Otero \& Gayet (1996, character 11) proposed that a caudal fin with a maximum of 18 principal rays (our character 58, $0 \rightarrow 1$ ) was another synapomorphy of Euacanthomorpha. The optimization of this character state is ambiguous. 


\section{LAMPRIDOMORPHA}

We propose to name Lampridomorpha the clade that unites Lampridiformes with $\dagger$ Pycnosteroididae, $\uparrow$ Pharmacichthyidae and $†$ Aipichthyoidea (Fig. 6, clade A). This name was already used in several studies (e.g McCune \& Carlson, 2004; Dillman et al., 2011) sometimes as "Lampriomorpha" (Nelson, 2006) or "Lampridacea" (Wiley \& Johnson, 2010), but always as a superorder with a taxonomic composition identical to the order Lampridiformes. Lampridomorpha is sister to Euacanthomorpha, therefore we suggest for subsequent workers to use this name for grouping Lampridiformes and all fossil taxa most closely related to them than to any other extant acanthomorph taxon (i.e. total-group Lampridiformes).

Included taxa: $\uparrow$ Pycnosteroides levispinosus (Hay, 1903); $\uparrow$ Pharmacichthys venenifer Smith Woodward, 1942; †P. numismalis Gayet, 1980a; $\uparrow P$. judensis Gayet, 1980b; $\uparrow$ Aipichthys minor (Pictet, 1850); $\uparrow$ A. velifer Smith Woodward, 1901; $\uparrow$ A. oblongus Gayet, 1980a; $\uparrow$ Paraipichthys lusitanicus Gaudant, 1978; $\uparrow$ Freigichthys elleipsis Otero, 1997; $\uparrow$ Aipichthyoides galeatus Gayet, 1980b; †Aspesaipichthys cavaensis Taverne, 2004; $\dagger$ Zoqueichthys carolinae Alvarado-Ortega \& Than-Marchese, 2012; Lampridiformes. Presumably included taxa (not present in our analysis): $\uparrow$ Aipichthys nuchalis (Dixon, 1850); $\dagger$ A. pretiosus Steindachner, 1860; $\uparrow$ Aipichthyoides formosus Gayet, 1980b; $\dagger$ Errachidia pentaspinosa Murray \& Wilson, 2014; †Homalopagus multispinosus Murray \& Wilson, 2014; $\dagger$ Magrebichthys nelsoni Murray \& Wilson, 2014.

These taxa present most of the synapomorphies that characterise Lampridomorpha (see below). $\dagger$ Errachidia and $\dagger$ Homalopagus are retained as Lampridomorpha incertae sedis, as Murray \& Wilson (2014: fig. 12) found in their analysis (although they considered them to be $\uparrow$ Aipichthyoidea incertae sedis and included no living lampridomorphs in their analysis).

Within Lampridomorpha, our topology challenges the taxonomy established by previous studies. Indeed, Otero \& Gayet's (1996) †Aipichthyoidea is not monophyletic: some of its representatives are most closely related to crown Lampridiformes, while others are grouped with the $\uparrow$ Pycnosteroididae $+\uparrow$ Pharmacichthyidae clade.

Furthermore, family $\dagger$ Aipichthyidae sensu Alvarado-Ortega \& Than-Marchese (2012), is paraphyletic according to the position of $\uparrow$ Paraipichthys as sister to all other members of clade B. The genus $\uparrow$ Aipichthys is also paraphyletic, or should include $\uparrow$ Freigichthys, a taxonomic revision already suggested by Alvarado-Ortega \& Than-Marchese (2012: fig. 8). 
Finally, family $\dagger$ Aipichthyoididae as proposed by these authors is also challenged by our results, $\uparrow$ Aipichthyoides and $\uparrow$ Aspesaipichthys being part of clade $\mathrm{D}$, but not $\uparrow$ Zoqueichthys.

Our results therefore imply that, instead of forming a clade, $\uparrow$ Aipichthyoidea as a whole is a paraphyletic assemblage of Late Cretaceous acanthomorphs, more or less closely related to extant lampridiforms.

We found nine potential synapomorphies for Lampridomorpha, including eight whose optimisation is unambiguous.

1. Loss of the antorbital (character $7,0 \rightarrow 1$ ).

It also occurs convergently in extant paracanthopterygians.

2. Ascending process on the lachrymal (character $8,0 \rightarrow 1$ ).

It is present in $†$ 'aipichthyoids' and $\uparrow$ Pycnosteroides, but appears independently in paracanthopterygians (Patterson \& Rosen, 1989). It is optimised as lost in $\dagger$ pharmacichthyids and lampridiforms.

3. Single-headed cranial articular condyle on the hyomandibula (character $25,0 \rightarrow 1$ ). Despite Oelschläger's (1983: 108) interpretation of the double-headed articular condyle as an "advanced" feature of percomorphs, the same state (Fig. 1D) occurs in myctophiforms (Paxton, 1972) and aulopiforms, suggesting that it is plesiomorphic for acanthomorphs. Therefore, we view the reduction to only one condyle as a derived character state of lampridomorphs (Fig. 1E, F), acquired convergently by some paracanthopterygians (Grande et al., 2013) and by $\dagger$ Ctenothrissa.

4. All supraneurals anterior to the first neural spine (Fig. 2A, B; character 39, $0 \rightarrow 1$ ). The state is reversed in $\uparrow$ Pycnosteroides.

5. First dorsal pterygiophore inserting anterior to the second neural spine (Fig. 2A, B; character $40,0 \rightarrow 1)$.

This character is further derived in lampridiforms (Fig. 2B), $\uparrow$ Pycnosteroides and two species of $\uparrow$ Pharmacichthys, where the first dorsal pterygiophore inserts anterior to the first neural spine.

6. First soft ray of the dorsal fin elongated and unbranched (character $43,0 \rightarrow 1$ ).

In $\uparrow$ Aipichthys (Fig. 2A), for example, the anterior-most dorsal fin ray that is branched is the second one. In taeniosome lampridiforms, all dorsal fin rays are unbranched. In all these cases, the first dorsal ray is also the longest (not visible in Fig. 2).

We infer a reversal in $\uparrow$ Pycnosteroides, where all dorsal fin rays are branched.

7. Pelvic girdle contacting the coracoids medially (character $63,0 \rightarrow 1$ ). 
Contact between the pelvic and pectoral girdles is common in acanthomorphs, as described by Stiassny \& Moore (1992), but it can occur in different ways. In Polymixia and Aphredoderus, there is no contact. In Merluccius (Fig. 4A) and Myripristis, the pelvic girdle contacts the cleithra, but not the coracoids. In fossil lampridomorphs (Fig. 4B), it is unclear if it contacts both coracoids and cleithra, or just coracoids. In Lampridiformes (Fig. 4C) the pelvic girdle contacts an enlarged and ventrally expanded coracoid (Le Danois, 1955) - incorrectly referred to as an "hypocoracoid" by Gill (1903).

8. Pelvic bones joined medially by their internal wings (character 64, $0 \rightarrow 1$ ).

This character also occurs in most euacanthopterygians, but not in polymixiiforms (Fig. 4D) or paracanthopterygians. While the character state is observable only in two of our fossil taxa (†Freigichthys and $\uparrow$ Zoqueichthys; Fig. 4E), their respective positions in the final tree favours the interpretation that it appeared in the last common ancestor of lampridomorphs.

The following feature can also be optimised as a ctenosquamate synapomorphy:

9. Hypurostegy of the caudal fin rays (character 58, $0 \rightarrow 1$ ).

The character is also present (amongst many others) in myctophids and in numerous euacanthopterygians (e.g. scombrids, carangids, luvarids, xiphioids). It is noteworthy that this ambiguous synapomorphy was the main argument that Patterson $(1968,1993)$ and later authors (e.g. Olney et al., 1993) mentioned to justify a relationship between †aipichthyoids (Fig. 3D) and lampridiforms (Fig. 3E).

Otero \& Gayet (1996) proposed four synapomorphies for their $\uparrow$ Aipichthyoidea. Here we demonstrate that three of these (the loss of the antorbital, the anterior insertion of the supraneurals and the contact between pelvic and pectoral girdles) in fact characterize a more inclusive clade: they can be assigned without ambiguity to Lampridomorpha. Their last putative synapomorphy of †aipichthyoids (plate-like process on the hyomandibula: character $26,0 \rightarrow 1$ ) is unambiguously optimised as a ctenosquamate synapomorphy. Therefore, our data do not support any synapomorphies for $\uparrow$ Aipichthyoidea, which we regard as a nonmonophyletic assemblage.

Some other character reconstructions of the present study are worth mentioning. For example, the true pelvic spine (character $67,0 \rightarrow 1$ ) was thought to be a diagnostic character of acanthopterygians (Stiassny \& Moore, 1992; Johnson \& Patterson, 1993). There is a pelvic spine in at least two lampridomorphs, however: $\uparrow$ Pycnosteroides (Fig. 4B) and 
$\dagger$ Magrebichthys (Murray \& Wilson, 2014). Murray \& Wilson (2014) also described a spine in the pelvic fins of $\dagger$ Errachidia and $\dagger$ Homalopagus, but this interpretation is questionable because the structures are incomplete, and can also be interpreted as enlarged and unbranched soft rays (as in $\dagger$ Aipichthys). Therefore, when our data are considered, pelvic spines appeared at least twice independently: in Euacanthopterygii and in certain lampridomorphs.

\section{UNNAMED CLADE B}

Included taxa: $\uparrow$ Pycnosteroides levispinosus (Hay 1903), $\uparrow$ Pharmacichthys venenifer Smith Woodward 1942, $\uparrow P$. numismalis Gayet 1980a, $\dagger P$. judensis Gayet 1980b, $\uparrow$ Aipichthys minor (Pictet 1850), $\uparrow$ A. velifer Smith Woodward 1901, $\uparrow A$. oblongus Gayet 1980a, $\uparrow$ Paraipichthys lusitanicus Gaudant 1978, †Freigichthys elleipsis Otero 1997.

Presumably included taxa (not present in our analysis): $\uparrow$ Aipichthys nuchalis (Dixon 1850), $\uparrow$ A. pretiosus Steindachner 1860; †Magrebichthys nelsoni Murray \& Wilson, 2014.

This clade (Fig. 6, clade B) is supported by only one synapomorphy:

1. Six or fewer soft rays in the pelvic fin (character $66,0 \rightarrow 2$ ).

The state is reversed in $\dagger$ Freigichthys, and also present in Trachipterus + Regalecus. The state of this character is unknown for $\uparrow$ Aipichthys oblongus.

\section{UNNAMED CLADE C}

Included taxa: $\uparrow$ Aipichthyoides galeatus Gayet 1980b, $\uparrow$ Aspesaipichthys cavaensis Taverne 2004, †Zoqueichthys carolinae Alvarado-Ortega \& Than-Marchese 2012, Lampridiformes. Presumably included taxa (not present in our analysis): $\uparrow$ Aipichthyoides formosus Gayet $1980 b$.

This clade (Fig. 6, clade C) is supported by two synapomorphies, both unique to it:

1. Frontal bone forming part of the sagittal crest (Fig. 1B, C), which usually (Fig. 1A) consists of the supraoccipital only (character 17, $0 \rightarrow 1$ ).

2. Long sagittal crest (Fig. 1B, C), extending from the nasal area to the occiput (character $20,0 \rightarrow 1)$.

Both synapomorphies are unknown in $\dagger$ Aspesaipichthys, due to its incomplete preservation. They are reversed in taeniosome lampridiforms (Trachipterus + Regalecus), which are characterised by reduced crests. 


\section{UNNAMED CLADE D}

Included taxa: $\uparrow$ Aipichthyoides galeatus Gayet 1980b, $\uparrow$ Aspesaipichthys cavaensis Taverne 2004, Lampridiformes.

Presumably included taxa (not present in our analysis): $\uparrow$ Aipichthyoides formosus Gayet 1980b.

This clade (Fig. 6, clade D) is supported by three synapomorphies:

1. Mesethmoid median or posterior to the lateral ethmoids (character $6,0 \rightarrow 1$ ).

In acanthomorphs, the mesethmoid is generally located anterior to the lateral ethmoids (Fig. 1A). In †Aipichthyoides, the mesethmoid composes the sagittal crest; dorsally it is median to the lateral ethmoids (Fig. 1B). In lampridiforms (Olney et al., 1993: 148), the mesethmoid is partly median, partly posterior (Fig. 1C), or completely posterior (in taeniosomes) to the lateral ethmoids.

2. Five hypurals or fewer (character $51,0 \rightarrow 1$ ).

There is a reversal in veliferids (Fig. 3C), a convergence in euacanthopterygians and some paracanthopterygians.

3. Lower hypurals fused together (character $54,0 \rightarrow 1$ ).

In $\uparrow$ Aipichthyoides, $\uparrow$ Aspesaipichthys (Fig. 3B) and veliferids (Fig. 3C), hypurals one and two are joined together at the base, thus partially fused together. The fusion is complete in Lampris. This state is convergent in Aphredoderus and Merluccius.

\section{LAMPRIDIFORMES GOODRICH, 1909}

Synonyms: Allotriognathi Regan, 1907; Lampriformes Goodrich, 1909.

Remark: A debate exists on whether the order should be named "Lampriformes" or "Lampridiformes". "Lampriformes" has been used several times following the recommendations of Steyskal (1980), for example in Olney (1984), Grande et al. (2013) and most notably, in Nelson's widely used handbook Fishes of the World (Nelson, 2006) as well as in the online database FishBase (Froese \& Pauly, 2014; http://www.fishbase.org). However, Patterson, in an appendix to Olney et al. (1993), advocated the use of "Lampridiformes". This orthography has been followed by the vast majority of recent phylogenetic papers, including the review of teleost classification by Wiley \& Johnson (2010) and the DeepFin-EToL classification (Betancur-R. et al., 2013b).Therefore, we chose to maintain current usage and use the name "Lampridiformes". Included taxa: see reviews in Olney et al., 1993; Roberts, 2012. 
Olney et al. (1993) proposed four osteological synapomorphies for Lampridiformes. All of these were retrieved here (one has an ambiguous optimisation and another is not a discrete character state in our matrix) and we propose additional ones, for a total of 14 synapomorphies (four cannot be unambiguously assigned to the clade because of missing data in the fossil sister groups).

1. Ascending process of the premaxilla equal or longer than the alveolar process (character $2,0 \rightarrow 1)$.

An elongate ascending process is a lampridiform synapomorphy according to Olney et al. (1993: 148).

2.Loss of the supramaxillae (character $3,0 \rightarrow 2$ ).

It is also the case in modern paracanthopterygians and in myctophids, by convergence.

3. Loss of the anterior palatine process (character $4,0 \rightarrow 1$ ).

This lampridiform synapomorphy according to Olney et al. (1993: 147) is here optimised as ambiguous, because the character state data are missing for the immediate fossil outgroups in our matrix.

4. Loss of the ascending process on the lachrymal (character $8,1 \rightarrow 0$ ).

This is a reversal of Lampridomorpha character number one.

5. "Vault" or "cradle" on the frontal, accommodating the premaxilla and the rostral cartilage (character $12,0 \rightarrow 1$ ).

This state is part of Olney et al.'s (1993: 148) synapomorphy number three.

6. Seven or fewer branchiostegal rays (character $28,1 \rightarrow 2$ ).

This state is convergent with paracanthopterygians and Polymixia.

7. Urohyal expanded by a large ventral lamina (Fig. $1 \mathrm{H}$; character 29, $0 \rightarrow 1$ ).

The optimisation is ambiguous for this state because of missing data in fossils. A large ventral lamina on the urohyal is also present in many deep-bodied euacanthopterygians not included in the analysis like menids and some carangids.

8. Epineurals lost on the postabdominal vertebrae (character $36,0 \rightarrow 1$ ).

This state is convergent with extant paracanthopterygians.

9. Loss of the epipleurals (character 37, $0 \rightarrow 1$ ).

An independent loss occurred in Euacanthopterygii+Paracanthopterygii and in $\dagger$ Pycnosteroides

10. Only two supraneurals (character $38,0 \rightarrow 2$ ). 
All Lampridiformes included in our analysis have one supraneural at most (hence the character state presented here). However, Velifer hypselopterus (not included) is the only extant species with two supraneurals (Fig. 2B), suggesting that the reduction to two supraneurals is the lampridiform synapomorphy. Such a reduction is convergent with paracanthopterygians and Myripristis.

11. First dorsal pterygiophore inserting anterior to the first neural spine (Fig. 2B; character $40,1 \rightarrow 2)$.

This character state is also observed (by convergence) in the $\uparrow$ Pharmacichthys + $\uparrow$ Pycnosteroides clade (with a reversion in $\uparrow$ Pharmacichthys venenifer) and in euacanthopterygians not included in the analysis such as echeneids, pleuronectoids, pataecids and coryphaenids.

12. Upper hypurals fused together (Fig. 3B, C; character $52,0 \rightarrow 1$ ).

The character can also be considered a synapomorphy of a potential $\uparrow$ Aspesaipichthys+Lampridiformes clade (recovered in several parsimonious trees), convergent with modern paracanthopterygians.

13. Upper hypurals fused to the second ural centrum (Fig. 3C; character 53, $0 \rightarrow 1$ ). While it could also be interpreted as convergent in lampridids and veliferids, we follow Wiley \& Johnson (2010), who favoured this character state as a lampridiform synapomorphy - as already noted by Patterson (1968). There is a reversal in taeniosomes, which have greatly modified caudal skeletons presumably associated with reduction of the caudal fin. The state is also convergent with extant paracanthopterygians.

14. Postcleithra fused together (character $61,0 \rightarrow 1$ ).

This state is convergent with extant paracanthopterygians.

Our results are consistent with the previous ones regarding relationships within Lampridiformes (e.g. Olney et al., 1993; Wiley et al., 1998): veliferids are sister to a clade composed by lampridids and taeniosomes.

\section{CONCLUSIONS}

For the first time, Late Cretaceous acanthomorphs of uncertain affinities are included in a phylogenetic analysis along with representatives of all the major acanthomorph subgroups. Thanks to this taxonomic sampling allowing a better comprehension of character state 
distribution among acanthomorphs, we are able to propose here new arguments concerning the phylogenetic position of Lampridiformes. Our results support a topology that is congruent with some previous works, both anatomical (Johnson \& Patterson, 1993; Olney et al., 1993) and molecular (Wiley et al., 1998, 2000; Smith \& Wheeler, 2006; Grande et al., 2013). The present study is thus a new example of the interest of including fossils in phylogenetic studies where the extant taxa have very modified anatomies leading to ambiguities in assessment of potential homologies (e.g. Santini \& Tyler, 2004; Friedman, 2012).

In addition to the position of Lampridiformes, we were able to clarify the relationships and taxonomy of the Cretaceous fossils we used, suggesting that $\uparrow$ "aipichthyoids", $\uparrow$ pharmacichthyids and †pycnosteroidids are indeed closely related to modern lampridiforms and demonstrating the paraphyly of $\uparrow$ Aipichthyoidea.

The clade Lampridomorpha has been expanded in its composition, as it now includes extinct lineages along with the extant Lampridiformes. Our results show (Fig. 7) that lampridomorphs were already present in the Cenomanian, which is about $20 \mathrm{Myr}$ earlier than the previously accepted oldest occurrence of the group (with $\uparrow$ Nardovelifer in the CampanianMaastrichtian). Thus, the oldest lampridomorphs are the same age as the oldest representatives of the other main acanthomorph subclades: Polymixiiformes (†Homonotichthys and $\dagger$ Omosoma from England, Lebanon and Morocco), Paracanthopterygii $(\dagger$ Xenyllion from North America) and Euacanthopterygii (diverse "beryciform" genera from Lebanon, Palestine, England, Portugal, Morocco, Slovenia and Mexico), which are all from the Cenomanian or Turonian (Patterson, 1993; Wilson \& Murray, 1996; Newbrey et al., 2013).

The present study offers a new glimpse of the early evolution of lampridiforms, and of acanthomorphs as a whole. We show that lampridomorphs were a diverse group in the Cretaceous, represented by at least 14 species in the Cenomanian, which is an important part of the total acanthomorph diversity known at the time. Consistent with other acanthomorph groups (Friedman, 2010; Near et al., 2013), it was later, in the Paleogene, that the clade diversified while developing numerous morphological innovations (Bannikov, 1999; Carnevale, 2004). These are the profound modification of the jaws articulations, reduction of spinous component of fins and adaptation to a pelagic environment that are characteristic of the extant Lampridiformes.

\section{ACKNOWLEDGEMENTS}


We would like to thank Gaël Clément, Philippe Béarez, Patrice Pruvost, Romain Causse, Zora Gabsi (MNHN), Martha Richter, Zerina Johanson, Emma Bernard, James Maclaine (NHMUK), Marcus A. Krag (ZMUC), David Johnson (NMNH), Barbara Brown and Radford Arrindell (AMNH) for access to collections or specimens under their care. Guy Duhamel and Mélyne Hautecoeur (MNHN) are thanked for providing specimens from the Southern Ocean, as well as Anthony Herrel (MNHN) for access to dissection facilities, François Meunier and Hugo Dutel (MNHN) for help during dissections and Eric Pellé (MNHN) for osteological preparations. CT-scannings were performed at the AST-RX, Plateforme d'accès scientifique à la tomographie à rayons X, UMS 2700 Outils et Méthodes de la Systématique Intégrative (CNRS/MNHN), with the help of Miguel García-Sanz for data acquisition, Florent Goussard and Damien Germain (MNHN) for data treatment. Fabrice Fack (MNHN) provided PAUP 3.0 emulated with SheepShaver, as well as thorough discussion on phylogenetics. Niels Bonde, Bouziane Khalloufi, Bruno Chanet, and Nalani Schnell are warmly thanked for their helpful discussions and comments at different stages of the work. Critical comments and advice by Alison Murray and an anonymous reviewer greatly improved the present paper. D. Davesne is supported by funding from ATM "Formes possibles, formes réalisées" (MNHN).

\section{REFERENCES}

Alvarado-Ortega J, Brito PM. 2011. A new species of Araripichthys (Teleostei, Elopocephala) from the Tlayúa Formation (Cretaceous, Albian), Mexico. Journal of Vertebrate Paleontology 31: 1376-1381.

Alvarado-Ortega J, Than-Marchese BA. 2012. A Cenomanian aipichthyoid fish (Teleostei, Acanthomorpha) from America, Zoqueichthys carolinae gen. and sp. nov. from El Chango quarry (Cintalapa Member, Sierra Madre Formation), Chiapas, Mexico. Revista Mexicana de Ciencias Geológicas 29: 735-748.

Bannikov AF. 1990. An Eocene veliferoid (Teleostei, Lampridiformes) from Bolca. Studi e Ricerche sui Giacimenti Terziari di Bolca 6: 161-174.

Bannikov AF. 1999. A review of fossil Lampridiformes (Teleostei) finds with a description of a new Lophotidae genus and species from the Oligocene of the Northern Caucasus. Paleontological Journal 33: 68-76.

Betancur-R. R, Broughton RE, Wiley EO, Carpenter K, López JA, Li C, Holcroft NI, Arcila D, Sanciangco M, Cureton JC, et al. 2013a. The tree of life and a new classification of bony fishes. PLoS Currents Tree of Life 2013 Apr 18. Edition 1.

Betancur-R, R, Wiley E, Miya M, Lecointre G, Bailly N, Ortí G. 2013b. New and Revised Classification of Bony Fishes Version 2 (http://www.deepfin.org/Classification_v2.htm).

Carnevale G. 2004. The first fossil ribbonfish (Teleostei, Lampridiformes, Trachipteridae). Geological Magazine 141: 573-582. 
Cavin L. 2001. Osteology and phylogenetic relationships of the teleost Goulmimichthys arambourgi Cavin, 1995, from the Upper Cretaceous of Goulmima, Morocco. Eclogae Geologicae Helvetiae 94: 509-535.

Cobbett A, Wilkinson M, Wills MA. 2007. Fossils impact as hard as living taxa in parsimony analyses of morphology. Systematic Biology 56: 753-766.

Dettaï A, Lecointre G. 2005. Further support for the clades obtained by multiple molecular phylogenies in the acanthomorph bush. Comptes Rendus Biologies 328: 674-689.

Dettaï A, Lecointre G. 2008. New insights into the organization and evolution of vertebrate IRBP genes and utility of IRBP gene sequences for the phylogenetic study of the Acanthomorpha (Actinopterygii: Teleostei). Molecular Phylogenetics and Evolution 48: 258-269.

Dillman CB, Bergstrom DE, Noltie DB, Holtsford TP, Mayden RL. 2011. Regressive progression, progressive regression or neither? Phylogeny and evolution of the Percopsiformes (Teleostei, Paracanthopterygii). Zoologica Scripta 40: 45-60.

Donoghue MJ, Doyle JA, Gauthier J, Kluge AG, Rowe T. 1989. The importance of fossils in phylogeny reconstruction. Annual Review of Ecology and Systematics 20: 431-460.

Faircloth BC, Sorenson L, Santini F, Alfaro ME. 2013. A phylogenomic perspective on the radiation of rayfinned fishes based upon targeted sequencing of ultraconserved elements (UCEs). PLoS ONE 8: e65923.

Felsenstein J. 1985. Confidence limits on phylogenies: using the bootstrap. Evolution 39: 783-791.

Friedman M. 2008. The evolutionary origin of flatfish asymmetry. Nature 454: 209-212.

Friedman M. 2010. Explosive morphological diversification of spiny-finned teleost fishes in the aftermath of the end-Cretaceous extinction. Proceedings of the Royal Society B: Biological Sciences 277: 1675-1683.

Friedman M. 2012. Osteology of $\dagger$ Heteronectes chaneti (Acanthomorpha, Pleuronectiformes), an Eocene stem flatfish, with a discussion of flatfish sister-group relationships. Journal of Vertebrate Paleontology 32: 735-756.

Friedman M, Johanson Z, Harrington RC, Near TJ, Graham MR. 2013. An early fossil remora (Echeneoidea) reveals the evolutionary assembly of the adhesion disc. Proceedings of the Royal Society B: Biological Sciences 280: 20131200

Froese R, Pauly D, eds. 2014. FishBase. World Wide Web electronic publication. www.fishbase.org, version $(02 / 2014)$

Gaudant M. 1978. Contribution à l'étude anatomique et systématique de l'ichthyofaune cénomanienne du Portugal. Première partie: les “acanthoptérygiens”. Comunicações dos Serviços Geológicos de Portugal 63: 105149.

Gauthier J, Kluge AG, Rowe T. 1988. Amniote phylogeny and the importance of fossils. Cladistics 4: 105-209.

Gayet M. 1979. La structure de la joue chez Pharmacichthys. Application à la recherche des affinités de ce poisson. Bulletin du Muséum national d'Histoire naturelle, Paris, Série C 1: 329-341.

Gayet M. 1980a. Contribution a l'étude anatomique et systématique des poissons cénomamiens du Liban, anciennement placés dans les acanthoptérygiens. Mémoires du Muséum national d'Histoire naturelle, Série C, Sciences de la Terre 44.

Gayet M. 1980b. Recherches sur l'ichthyofaune cénomanienne des Monts de Judée : les "acanthoptérygiens." Annales de Paléontologie (Vertébrés) 66: 75-128. 
Gayet M. 1980c. Relations phylogénétiques des poissons Eurypterygii non Acanthomorpha. Bulletin du Muséum national d'Histoire naturelle, Paris, Série C 2: 321-337.

Gayet M. 1982. Essai de définition des relations phylogénétiques des Holocentroidea nov. et des Trachichthyoidea nov. (Pisces, Acanthopterygii, Béryciformes). Bulletin du Muséum national d'Histoire naturelle, Paris, Série C 4: 21-41.

Gill T. 1903. On the relations of the fishes of the family Lamprididae or opahs. Proceeding of the US National Museum 26: 915-924.

Grande T, Borden WC, Smith WL. 2013. Limits and relationships of Paracanthopterygii: A molecular framework for evaluating past morphological hypotheses. In: Arratia G, Schultze HP, Wilson MVH, eds. Mesozoic Fishes 5 - Global Diversity and Evolution. Munich: Verlag Dr. Friedriech Pfeil, 385-418.

Greenwood PH, Rosen DE, Weitzman SH, Myers GS. 1966. Phyletic studies of teleostean fishes, with a provisional classification of living forms. Bulletin of the American Museum of Natural History 131: 341-455.

Johnson GD, Patterson C. 1993. Percomorph phylogeny: a survey of acanthomorphs and a new proposal. Bulletin of Marine Science 52: 554-626.

Le Danois Y. 1955. Sur la musculature des nageoires pectorales et pelviennes de l'opah (Lampris luna Duhamel). Bulletin de la Société Zoologique de France 53: 8-17.

Le Danois E, Le Danois Y. 1964. L'ordre des Scombres. Mémoires de l'Institut Fondamental d'Afrique Noire 68: $153-192$.

Li B, Dettaï A, Cruaud C, Couloux A, Desoutter-Meniger M, Lecointre G. 2009. RNF213, a new nuclear marker for acanthomorph phylogeny. Molecular Phylogenetics and Evolution 50: 345-363.

Maisey JG, Blum S. 1991. Araripichthys. In: Maisey JG, ed. Santana Fossils: an Illustrated Atlas. Neptune, New Jersey: TFH Publications, 208-217.

Maisey JG, Moody JM. 2001. A review of the problematic extinct teleost fish Araripichthys, with a description of a new species from the Lower Cretaceous of Venezuela. American Museum Novitates 3324: 1-27.

McCune AR, Carlson RL. 2004. Twenty ways to lose your bladder: common natural mutants in zebrafish and widespread convergence of swim bladder loss among teleost fishes. Evolution \& Development 6: 246-259.

Miya M, Takeshima H, Endo H, Ishiguro NB, Inoue JG, Mukai T, Satoh TP, Yamaguchi M, Kawaguchi A, Mabuchi K, et al. 2003. Major patterns of higher teleostean phylogenies: a new perspective based on 100 complete mitochondrial DNA sequences. Molecular Phylogenetics and Evolution 26: 121-138.

Miya M, Holcroft NI, Satoh TP, Yamaguchi M, Nishida M, Wiley EO. 2007. Mitochondrial genome and a nuclear gene indicate a novel phylogenetic position of deep-sea tube-eye fish (Stylephoridae). Ichthyological Research 54: 323-332.

Miya M, Kawaguchi A, Nishida M. 2001. Mitogenomic exploration of higher teleostean phylogenies: a case study for moderate-scale evolutionary genomics with 38 newly determined complete mitochondrial DNA sequences. Molecular Biology and Evolution 18: 1993-2009.

Miya M, Satoh TP, Nishida M. 2005. The phylogenetic position of toadfishes (order Batrachoidiformes) in the higher ray-finned fish as inferred from partitioned Bayesian analysis of 102 whole mitochondrial genome sequences. Biological Journal of the Linnean Society 85: 289-306.

Murray AM, Wilson MVH. 1999. Contributions of fossils to the phylogenetic relationships of the percopsiform fishes (Teleostei: Paracanthopterygii): order restored. In: Arratia G, Schultze HP, eds. Mesozoic Fishes 2 Systematics and Fossil Record. Munich: Verlag Dr. Friedriech Pfeil, 397-411. 
Murray AM, Wilson MVH. 2014. Four new basal acanthomorph fishes from the Late Cretaceous of Morocco. Journal of Vertebrate Paleontology 34: 34-48.

Near TJ, Eytan RI, Dornburg A, Kuhn KL, Moore JA, Davis MP, Wainwright PC, Friedman M, Smith WL. 2012. Resolution of ray-finned fish phylogeny and timing of diversification. PNAS 109: 13698-13703.

Near TJ, Dornburg A, Eytan RI, Keck BP, Smith WL, Kuhn KL, Moore JA, Price SA, Burbrink FT, Friedman M, et al. 2013. Phylogeny and tempo of diversification in the superradiation of spiny-rayed fishes. PNAS 110: 12738-12743.

Nelson JS. 2006. Fishes of the World. Hoboken, New Jersey: John Wiley \& Sons.

Newbrey MG, Murray AM, Wilson MVH, Brinkman DB, Neuman AG. 2013. A new species of the paracanthopterygian Xenyllion from the Mowry Formation (Cenomanian) of Utah, USA. In: Arratia G, Schultze HP, Wilson MVH, eds. Mesozoic Fishes 5 - Global Diversity and Evolution. Munich: Verlag Dr. Friedriech Pfeil, 363-384.

Oelschläger HA. 1974. Das Caudalskelett von Lampris regius und seine Ableitung von Velifer hypselopterus. Senckenbergiana Biologica 55: 77-85.

Oelschläger HA. 1976. On the evolution and ecological adaptations of the Allotriognathi. Revue des Travaux de l'Institut des Pêches Maritimes 40: 691-694.

Oelschläger HA. 1983. Vergleichende und funktionelle Anatomie der Allotriognathi (= Lampridiformes), ein Beitrag zur Evolutionsmorphologie der Knochenfische. Abhandlungen der Senckenbergischen Naturforschenden Gesellschaft 541: 1-127.

Olney JE. 1984. Lampriformes: development and relationships. In: Moser HG, ed. Ontogeny and Systematics of Fishes. American Society of Ichthyologists and Herpetologists Special Publication 1: 368-379.

Olney JE, Johnson GD, Baldwin CC. 1993. Phylogeny of lampridiform fishes. Bulletin of Marine Science 52: 137-169.

Otero O. 1997. Un nouveau genre d'Aipichthyoidea (Teleostei, Acanthomorpha) du Cénomanien inférieur marin de Hgula (Liban) : description et relations phylogénétiques. Comptes rendus de l'Académie des sciences, Paris, Sciences de la Terre et des planètes 325: 453-458.

Otero O, Gayet M. 1995. Etude phylogénétique des aipichthyides, poissons téléostéens de la Téthys cénomanienne. Geobios 19: 221-224.

Otero O, Gayet M. 1996. Anatomy and phylogeny of the Aipichthyoidea nov. of the Cenomanian Tethys and their place in the Acanthomorpha (Teleostei). Neues Jahrbuch für Geologie und Paläontologie-Abhandlungen 202: 313-344.

Patterson C. 1964. A review of Mesozoic acanthopterygian fishes, with special reference to those of the English Chalk. Philosophical Transactions of the Royal Society of London. Series B. Biological Sciences 247: $213-482$.

Patterson C. 1968. The caudal skeleton in Mesozoic acanthopterygian fishes. Bulletin of the British Museum (Natural History) Geology 17: 47-102.

Patterson C. 1981. Significance of fossils in determining evolutionary relationships. Annual Review of Ecology and Systematics 12: 195-223.

Patterson C. 1993. An overview of the early fossil record of acanthomorphs. Bulletin of Marine Science 52: 2959. 
Patterson C, Rosen DE. 1989. The Paracanthopterygii revisited: order and disorder. In: Cohen DD, ed. Papers on the Systematics of Gadiform Fishes. Science Series of the Natural History Museum of Los Angeles County 32: $5-36$.

Paxton JR. 1972. Osteology and relationships of the lanternfishes (family Myctophidae). Bulletin of the Natural History Museum of Los Angeles County 13.

Poulsen JY, Byrkjedal I, Willassen E, Rees D, Takeshima H, Satoh TP, Shinohara G, Nishida M, Miya M. 2013. Mitogenomic sequences and evidence from unique gene rearrangements corroborate evolutionary relationships of myctophiformes (Neoteleostei). BMC Evolutionary Biology 13: 111.

Radovčić J. 1975. Some new Upper Cretaceous teleosts from Yugoslavia with special reference to localities, geology and palaeoenvironment. Palaeontologia Jugoslavica 17: 1-55.

Regan CT. 1907. On the anatomy, classification, and systematic position of the teleostean fishes of the suborder Allotriognathi. Proceedings of the Zoological Society of London 1907: 634-643.

Roberts TR. 2012. Systematics, Biology and Distribution of the Species of the Oceanic Oarfish Genus Regalecus (Teleostei, Lampridiformes, Regalecidae). Paris: Publications Scientifiques du Muséum.

Rosen DE, Patterson C. 1969. The structure and relationships of the paracanthopterygian fishes. Bulletin of the American Museum of Natural History 141: 357-474.

Santini F, Tyler JC. 2004. The importance of even highly incomplete fossil taxa in reconstructing the phylogenetic relationships of the Tetraodontiformes (Acanthomorpha: Pisces). Integrative and Comparative Biology 44: 349-357.

Smith WL, Wheeler WC. 2006. Venom evolution widespread in fishes: a phylogenetic road map for the bioprospecting of piscine venoms. The Journal of Heredity 97: 206-217.

Sorbini C, Sorbini L. 1999. The Cretaceous fishes of Nardò. $10^{\circ}$. Nardovelifer altipinnis, gen. nov. et sp. nov. (Teleostei, Lampridiformes, Veliferidae). Studi e Ricerche sui Giacimenti Terziari di Bolca 8: 11-27.

Sorenson MD. 1999. TreeRot, version 2. Boston University, Boston, MA.

Steyskal GC. 1980. The grammar of family-group names as exemplified by those of fishes. Proceedings of the Biological Society of Washington 93: 168-177.

Stiassny MLJ. 1986. The limits and relationships of the acanthomorph teleosts. Journal of Zoology (B) 1: 411460.

Stiassny MLJ, Moore JA. 1992. A review of the pelvic girdle of acanthomorph fishes, with comments on hypotheses of acanthomorph intrarelationships. Zoological Journal of the Linnean Society 104: 209-242.

Swofford DL. 2001. PAUP*, Phylogenetic Analysis Using Parsimony *and other methods, Version 4.0

Documentation.

Swofford DL, Begle DP. 1993. PAUP, Phylogenetic Analysis Using Parsimony, Version 3.1, User's manual.

Taverne L. 2004. Les poissons crétacés de Nardò. $17^{\circ}$. Aspesaipichthys cavaensis gen. et sp. nov. (Teleostei, Acanthomorpha, Aipichthyoidea). Bollettino del Museo Civico di Storia Naturale di Verona 28: 3-15.

Wiley EO, Johnson GD. 2010. A teleost classification based on monophyletic groups. In: Nelson JS, Schultze HP, Wilson MVH, eds. Origin and Phylogenetic Interrelationships of Teleosts. Munich: Verlag Dr. Friedriech Pfeil, 123-182. 
Wiley EO, Johnson GD, Dimmick WW. 1998. The phylogenetic relationships of lampridiform fishes (Teleostei: Acanthomorpha), based on a total-evidence analysis of morphological and molecular data. Molecular Phylogenetics and Evolution 10: 417-425.

Wiley EO, Johnson GD, Dimmick WW. 2000. The interrelationships of Acanthomorph fishes: a total evidence approach using molecular and morphological data. Biochemical Systematics and Ecology 28: 319-350.

Wilson MVH, Murray AM. 1996. Early Cenomanian acanthomorph teleost in the Cretaceous Fish Scale Zone, Albian/Cenomanian boundary, Alberta, Canada. In: Arratia G, Viohl G, eds. Mesozoic Fishes - Systematics and Paleoecology. Munich: Verlag Dr. Friedriech Pfeil, 369-382.

Wu K, Shen S. 2004. Review of the teleostean adductor mandibulae and its significance to the systematic positions of the Polymixiiformes, Lampridiformes, and Triacanthoidei. Zoological Studies 43: 712-736. 


\section{TABLES}

Table 1: List of the specimens used to code the characters in the study.

Column 1 = taxon name; column 2 = specimen number; column $3=$ technique(s) used.

Institutional abbreviations: AMNH = American Museum of Natural History, New York City,

USA; AMS = Australian Museum, Sydney, Australia; MNHN = Muséum national d'Histoire

naturelle, Paris, France; NHMUK = Natural History Museum, London, UK; ZMUC =

Zoological Museum - University of Copenhagen, Denmark

\begin{tabular}{|c|c|c|}
\hline \multicolumn{3}{|l|}{ Outgroups } \\
\hline Synodus intermedius & ZMUC P2394016 & direct observation and photos \\
\hline Gymnoscopelus sp. & MNHN research collection & $\begin{array}{l}\text { dissection, X-ray computed } \\
\text { tomography }\end{array}$ \\
\hline$\dagger$ Ctenothrissa protodorsalis & MNHN.F.HAK22 & binocular microscope \\
\hline$\dagger$ †tenothrissa signifer & NHMUK PV P47524 & binocular microscope and photos \\
\hline$\dagger$ Ctenothrissa vexillifer & MNHN.F.HAK39 & binocular microscope \\
\hline$\dagger$ Ctenothrissa vexillifer & MNHN.F.HAK104 & binocular microscope \\
\hline \multicolumn{3}{|c|}{ Potential Cretaceous sister-groups of Lampridiformes } \\
\hline$\dagger$ Pharmacichthys numismalis & MNHN.F.HAK3 & binocular microscope \\
\hline$\dagger$ Pharmacichthys venenifer & MNHN.F.HAK7 & binocular microscope \\
\hline$\dagger$ Aipichthys minor & MNHN.F.HAK1938 & binocular microscope \\
\hline$\dagger$ Aipichthys minor & MNHN.F.HAK94 & binocular microscope \\
\hline$\dagger$ Aipichthys velifer & MNHN.F.HAK57 & binocular microscope \\
\hline$\dagger$ Aipichthys velifer & NHMUK PV P4743 & binocular microscope and photos \\
\hline$\dagger$ †Apichthys velifer & NHMUK PV P4744 & binocular microscope and photos \\
\hline$\dagger$ Pycnosteroides levispinosus & MNHN.F.HDJ105 & binocular microscope \\
\hline$\dagger$ Pycnosteroides levispinosus & NHMUK PV P13901 & binocular microscope and photos \\
\hline \multicolumn{3}{|l|}{ Polymixiiformes } \\
\hline Polymixia cf.nobilis & MNHN.IC.2006-1740 & $\begin{array}{l}\text { X-ray radiographs of alcohol } \\
\text { specimen, X-ray computed } \\
\text { tomography }\end{array}$ \\
\hline Polymixia nobilis & NHMUK 95.5.28.1 & direct observation and photos \\
\hline \multicolumn{3}{|l|}{ Paracanthopterygii } \\
\hline Aphredoderus sayanus & MNHN.IC.1987-0864 & $\begin{array}{l}\text { X-ray radiographs of alcohol } \\
\text { specimen }\end{array}$ \\
\hline$†$ Sphenocephalus fissicaudus & NHMUK PV P8772 & binocular microscope and photos \\
\hline$†$ Sphenocephalus fissicaudus & NHMUK PV P8774 & binocular microscope and photos \\
\hline Merluccius merluccius & Research collection & dissection \\
\hline Merluccius merluccius & ZMUC 215 & direct observation and photos \\
\hline \multicolumn{3}{|l|}{ Euacanthopterygii } \\
\hline Myripristis sp. & Research collection & dissection \\
\hline \multicolumn{3}{|l|}{ Lampridiformes } \\
\hline Velifer hypselopterus & MNHN.IC.1982-0025 & $\begin{array}{l}\text { X-ray radiographs of alcohol } \\
\text { specimens, X-ray computed } \\
\text { tomography }\end{array}$ \\
\hline Velifer hypselopterus & AMS 21840020 & cleared and stained, photos \\
\hline Metavelifer multiradiatus & AMNH 214663 SD & direct observation and photos \\
\hline Metavelifer multiradiatus & AMNH 219280 SD & direct observation and photos \\
\hline
\end{tabular}




\begin{tabular}{|lll|}
\hline Metavelifer multiradiatus & AMNH 91808 SD & direct observation and photos \\
\hline Metavelifer multiradiatus & AMNH 91800 SD & direct observation and photos \\
\hline Metavelifer multiradiatus & AMNH 91798 SD & direct observation and photos \\
\hline Lampris guttatus & ZMUC 74 & direct observation and photos \\
\hline Lampris guttatus & AMNH 79669 SD & direct observation and photos \\
\hline Lampris guttatus & AMNH 21720 SD & direct observation and photos \\
\hline Lampris guttatus & MNHN.ZA.1883-1795 & direct observation \\
\hline Lampris immaculatus & MNHN research collection & dissection \\
\hline Lampris sp. & AMNH 21766 SD & direct observation and photos \\
\hline Trachipterus arcticus & ZMUC 1890 31 & direct observation and photos \\
\hline Trachipterus arcticus & AMNH 79627 SD & direct observation and photos \\
\hline Trachipterus jacksonensis & AMNH 098555 SD & direct observation and photos \\
\hline Trachipterus jacksonensis & AMNH 093409 SD & direct observation and photos \\
\hline Regalecus glesne & AMNH 093518 SD & direct observation and photos \\
\hline
\end{tabular}


Table 2: List of the characters used in the study. Column $1=$ character number; column $2=$ character description; column 3 = references.

\begin{tabular}{|c|c|c|}
\hline 1 & $\begin{array}{l}\text { Postmaxillary process of the premaxilla: } 0=\text { absent; } 1= \\
\text { present } ; 2=\text { present with a "gadoid" notch }\end{array}$ & Patterson \& Rosen, 1989 \\
\hline 2 & $\begin{array}{l}\text { Ascending process of the premaxilla: } 0=\text { shorter than the } \\
\text { alveolar process; } 1=\text { equal to or longer than the alveolar } \\
\text { process }\end{array}$ & Olney et al., 1993: character 3, in part \\
\hline 3 & Number of supramaxillae: $0=$ two $; 1=$ one $; 2=$ none & $\begin{array}{l}\text { Otero \& Gayet, 1996: characters 24, } 31 \text { \& } \\
\text { 46; Alvarado-Ortega \& Than-Marchese, } \\
\text { 2012: character } 28\end{array}$ \\
\hline 4 & Anterior palatine process: $0=$ present; $1=$ absent & Olney et al., 1993: character 1 \\
\hline 5 & $\begin{array}{l}\text { Lateral ethmoid: } 0=\text { not linked to the palate-quadrate } \\
\text { region; } 1=\text { linked to the palate-quadrate region by a narrow } \\
\text { process }\end{array}$ & Gayet, 1979 \\
\hline 6 & $\begin{array}{l}\text { Mesethmoid: } 0=\text { anterior to the lateral ethmoid (Fig. 1A); } 1 \\
=\text { median or posterior to the lateral ethmoid (Fig. } 1 \mathrm{~B}, \mathrm{C})\end{array}$ & Olney et al., 1993: character 2 \\
\hline 7 & Antorbital: $0=$ present $; 1=$ absent & Otero \& Gayet, 1996: character 14 \\
\hline 8 & Ascending process of the lachrymal: $0=$ absent; $1=$ present & Otero \& Gayet, 1996: character 39 \\
\hline 9 & $\begin{array}{l}\text { Supraorbital sensory canal: } 0=\text { fully ossified; } 1=\text { middle } \\
\text { and anterior part of the canal are not ossified }\end{array}$ & $\begin{array}{l}\text { Otero \& Gayet, 1996: characters } 29 \& 37 \text {; } \\
\text { Alvarado-Ortega \& Than-Marchese, 2012: } \\
\text { character } 32\end{array}$ \\
\hline 10 & Orbitosphenoid: $0=$ present $; 1=$ absent & Otero \& Gayet, 1996: character 38 \\
\hline 11 & Basisphenoid: $0=$ present; $1=$ absent & Otero \& Gayet, 1996: character 30 \\
\hline 12 & Frontal vault or cradle: $0=$ absent $; 1=$ present & Olney et al.,1993: character 3 , in part \\
\hline 13 & Interfrontal flat: $0=$ absent; $1=$ present & Otero \& Gayet, 1996: character 23 \\
\hline 14 & $\begin{array}{l}\text { Frontal branch of the sensory canal: } 0=\text { runs through the } \\
\text { frontal and pterotic in a closed tube; } 1=\text { runs through the } \\
\text { frontal and pterotic in a groove }\end{array}$ & Otero \& Gayet, 1996: character 2 \\
\hline 15 & $\begin{array}{l}\text { Preopercular branch of the sensory canal: } 0=\text { opens } \\
\text { throughout pores; } 1=\text { opens throughout an indentation }\end{array}$ & $\begin{array}{l}\text { Otero \& Gayet, 1996: characters } 3 \& \text { 25; } \\
\text { Alvarado-Ortega \& Than-Marchese, 2012: } \\
\text { character } 3\end{array}$ \\
\hline 16 & $\begin{array}{l}\text { Size of the sagittal crest (composed at least by the } \\
\text { supraoccipital): } 0=\text { absent or small crest; } 1=\text { developed } \\
\text { sagittal crest }\end{array}$ & $\begin{array}{l}\text { Olney et al., 1993: character 14; Otero \& } \\
\text { Gayet, 1996: character } 1\end{array}$ \\
\hline 17 & $\begin{array}{l}\text { Frontal bone forming part of the sagittal crest: } 0=\text { absent } \\
\text { (Fig. } 1 \mathrm{~A}) ; 1=\text { present }(\text { Fig. } 1 \mathrm{~B}, \mathrm{C})\end{array}$ & $\begin{array}{l}\text { Otero \& Gayet, 1996: character 18, in part; } \\
\text { Alvarado-Ortega \& Than-Marchese, 2012: } \\
\text { character } 18\end{array}$ \\
\hline
\end{tabular}




\begin{tabular}{|c|c|c|}
\hline 18 & $\begin{array}{l}\text { Mesethmoid bone forming part of the sagittal crest: } 0= \\
\text { absent (Fig. } 1 \mathrm{~A}, \mathrm{C}) ; 1=\text { present (Fig. } 1 \mathrm{~B})\end{array}$ & $\begin{array}{l}\text { Otero \& Gayet, 1996: character 18, in part; } \\
\text { Alvarado-Ortega \& Than-Marchese, 2012: } \\
\text { character } 19\end{array}$ \\
\hline 19 & $\begin{array}{l}\text { Posterior edge of the sagittal crest: } 0=\text { convex (rounded } \\
\text { crest, Fig. 1B, C); } 1=\text { concave (half-boomerang shaped } \\
\text { crest, Fig. 1A) }\end{array}$ & $\begin{array}{l}\text { Alvarado-Ortega \& Than-Marchese, 2012: } \\
\text { character } 20\end{array}$ \\
\hline 20 & $\begin{array}{l}\text { Length of the sagittal crest: } 0=\text { short, entirely behind the } \\
\text { orbit (Fig. } 1 \mathrm{~A}) ; 1=\text { long, from the nasal area to the occiput } \\
\text { (Fig. 1B, C) }\end{array}$ & $\begin{array}{l}\text { Alvarado-Ortega \& Than-Marchese, 2012: } \\
\text { character } 21\end{array}$ \\
\hline 21 & $\begin{array}{l}\text { Thickened anterior edge of the sagittal crest: } 0=\text { absent; } 1 \\
=\text { present }\end{array}$ & $\begin{array}{l}\text { Alvarado-Ortega \& Than-Marchese, 2012: } \\
\text { character } 22\end{array}$ \\
\hline 22 & $\begin{array}{l}\text { Dorsal limb of the posttemporal: } 0=\text { not firmly bound to } \\
\text { the epiotic; } 1=\text { firmly bound to the epiotic }\end{array}$ & $\begin{array}{l}\text { Stiassny, 1986; Johnson \& Patterson, 1993: } \\
\text { character } 5\end{array}$ \\
\hline 23 & Spina occipitalis: $0=$ absent $; 1=$ present & Otero \& Gayet, 1996: character 12 \\
\hline 24 & $\begin{array}{l}\text { Foramen magnum: } 0=\text { dorsal to the tripartite occipital } \\
\text { condyle; } 1=\text { bounded laterally by the exoccipital condyles }\end{array}$ & Olney et al., 1993: character 12 \\
\hline 25 & $\begin{array}{l}\text { Cranio-hyomandibular condyle: } 0=\text { two-headed (Fig. 1D); } \\
1=\text { single-headed (Fig. 1E, F) }\end{array}$ & $\begin{array}{l}\text { Oelschläger, 1983; Grande et al., 2013: } \\
\text { character } 6\end{array}$ \\
\hline 26 & $\begin{array}{l}\text { Plate-like anterior process of the hyomandibula: } 0=\text { absent; } \\
1=\text { present }\end{array}$ & Otero \& Gayet, 1996: character 15 \\
\hline 27 & $\begin{array}{l}\text { "Beryciform" foramen in the distal ceratohyal: } 0=\text { present; } \\
1=\text { absent }\end{array}$ & Oelschläger, 1983 \\
\hline 28 & $\begin{array}{l}\text { Number of branchiostegal rays: } 0=\text { nine or more; } 1=\text { eight; } \\
2=\text { seven or less }\end{array}$ & $\begin{array}{l}\text { Otero \& Gayet, 1996: characters 4, } 27 \text { \& 41; } \\
\text { Alvarado-Ortega \& Than-Marchese, 2012: } \\
\text { character } 4\end{array}$ \\
\hline 29 & $\begin{array}{l}\text { Urohyal: } 0=\text { not expanded ventrally (Fig. 1G); } 1= \\
\text { expanded by a large ventral lamina (Fig. } 1 \mathrm{H})\end{array}$ & New \\
\hline 30 & Posterior border of the preopercular: $0=$ smooth; $1=$ spiny & Otero \& Gayet, 1996: character 33 \\
\hline 31 & Posterior border of the opercular: $0=$ smooth $; 1=$ spiny & Otero \& Gayet, 1996: character 40 \\
\hline 32 & $\begin{array}{l}\text { Total number of vertebrae: } 0=\text { less than } 40 ; 1=40-60 ; 2= \\
60 \text { or more }\end{array}$ & Olney et al., 1993: characters $10 \& 25$ \\
\hline 33 & $\begin{array}{l}\text { Neural spines of vertebral centra (unknown for the first } \\
\text { neural spine of most fossils): } 0=\text { autogenous; } 1=\text { fused } \\
\text { with the centrum }\end{array}$ & Otero \& Gayet, 1996: character 5 \\
\hline 34 & $\begin{array}{l}\text { Orientation of the first neural spine: } 0=\text { inclined } \\
\text { posteriorly; } 1=\text { inclined anteriorly and in close association } \\
\text { with the cranium }\end{array}$ & Olney et al., 1993: character 16 \\
\hline 35 & Point of origin of anterior epineurals: $0=$ neural arches or & Otero \& Gayet, 1996: character 13 \\
\hline
\end{tabular}




\begin{tabular}{|c|c|c|}
\hline & spines; $1=$ centra or transverse processes & \\
\hline 36 & $\begin{array}{l}\text { Epineurals on the postabdominal vertebrae: } 0=\text { present; } 1 \\
=\text { absent }\end{array}$ & Otero \& Gayet, 1996: character 44 \\
\hline 37 & Epipleurals: $0=$ present; $1=$ absent & Otero \& Gayet, 1996: character 43 \\
\hline 38 & $\begin{array}{l}\text { Number of supraneurals (predorsals in Otero and Gayet } \\
\text { 1996): } 0=\text { three (Fig. 2A); } 1=\text { two (Fig. } 2 \text { B) } ; 2=\text { one; } 3= \\
\text { none }\end{array}$ & $\begin{array}{l}\text { Olney et al., 1993: character 13; Otero \& } \\
\text { Gayet, 1996: character 16, in part; Alvarado- } \\
\text { Ortega \& Than-Marchese, 2012: character } \\
16\end{array}$ \\
\hline 39 & $\begin{array}{l}\text { Position of supraneurals: } 0=\text { at least one posterior to the } \\
\text { first neural spine; } 1=\text { all anterior to the first neural spine } \\
\text { (Fig. } 2 \mathrm{~A}, \mathrm{~B} \text { ) }\end{array}$ & $\begin{array}{l}\text { Otero \& Gayet, 1996: character 16, in part; } \\
\text { Alvarado-Ortega \& Than-Marchese, 2012: } \\
\text { character } 17 \text {, in part }\end{array}$ \\
\hline 40 & $\begin{array}{l}\text { Position of the first dorsal pterygiophore: } 0=\text { posterior to } \\
\text { the second neural spine; } 1=\text { anterior to the second neural } \\
\text { spine (Fig. } 2 \text { A); } 2=\text { anterior to the first neural spine (Fig. } \\
\text { 2B) }\end{array}$ & Olney et al., 1993: character 4, in part \\
\hline 41 & $\begin{array}{l}\text { Orientation of the first two dorsal pterygiophores: } 0= \\
\text { vertical (Fig. } 2 \mathrm{~A}, \mathrm{~B}) ; 1=\text { inclined forward over } \\
\text { neurocranium }\end{array}$ & Olney et al., 1993: character 15 \\
\hline 42 & $\begin{array}{l}\text { Spines on the dorsal fin: } 0=\text { absent; } 1=\text { present (Fig. } 2 \mathrm{~A} \text {, } \\
\text { B) }\end{array}$ & Otero \& Gayet, 1996: character 6, in part \\
\hline 43 & $\begin{array}{l}\text { Elongated and unbranched first soft ray of the dorsal fin: } 0 \\
=\text { absent; } 1=\text { present }(\text { Fig. } 2 \mathrm{~A}, \mathrm{~B})\end{array}$ & New \\
\hline 44 & $\begin{array}{l}\text { Soft rays of the dorsal fin: } 0=\text { at least some branched rays; } \\
1=\text { all rays unbranched }\end{array}$ & Grande et al., 2013: character 15 \\
\hline 45 & Anal fin: $0=$ present; $1=$ absent & Olney et al., 1993: character 30 \\
\hline 46 & Hemaxanal complex: $0=$ absent; $1=$ present & Otero \& Gayet, 1996: character 7 \\
\hline 47 & Spines on the anal fin: $0=$ absent; $1=$ present & Otero \& Gayet, 1996: character 6, in part \\
\hline 48 & $\begin{array}{l}\text { Neural spine of the second preural vertebra: } 0=\text { short and } \\
\text { leaf-shaped; } 1=\text { long and spine-like }\end{array}$ & Otero \& Gayet, 1996: character 28 \\
\hline 49 & Stegural: $0=$ autogenous; $1=$ fused to the first ural centrum & Grande et al., 2013: character 26 \\
\hline 50 & Number of epurals: $0=$ three; $1=$ two & $\begin{array}{l}\text { Otero \& Gayet, 1996: characters } 19 \& 35 ; \\
\text { Alvarado-Ortega \& Than-Marchese, 2012: } \\
\text { character } 23\end{array}$ \\
\hline 51 & $\begin{array}{l}\text { Number of hypurals: } 0=\operatorname{six}(\text { Fig. } 3 \mathrm{~A}, \mathrm{C}) ; 1=\text { five or less } \\
\text { (Fig. 3B) }\end{array}$ & Otero \& Gayet, 1996: character 20 \\
\hline 52 & $\begin{array}{l}\text { Upper hypurals: } 0=\text { independent bones (Fig. } 3 \mathrm{~A}) ; 1=\text { fused } \\
\text { together }(\text { Fig. } 3 \mathrm{~B}, \mathrm{C})\end{array}$ & Otero \& Gayet, 1996: character 48 \\
\hline
\end{tabular}




\begin{tabular}{|c|c|c|}
\hline 53 & $\begin{array}{l}\text { Upper hypurals: } 0=\text { autogenous to the ural centra (Fig. 3A, } \\
\text { B); } 1=\text { fused to the second ural centrum (Fig. 3C) }\end{array}$ & Wiley \& Johnson, 2010: character 5 \\
\hline 54 & $\begin{array}{l}\text { Lower hypurals: } 0=\text { independent bones (Fig. 3A); } 1=\text { fused } \\
\text { together (Fig. 3B, C) }\end{array}$ & Grande et al., 2013: character 24 \\
\hline 55 & $\begin{array}{l}\text { Lower hypurals: } 0=\text { autogenous (Fig. 3A, C); } 1=\text { fused to } \\
\text { the pseudurostylar centrum (PU1+U1) (Fig. 3B) }\end{array}$ & Otero \& Gayet, 1996: character 21 \\
\hline 56 & Urodermals: $0=$ present; $1=$ absent & Otero \& Gayet, 1996: character 8 \\
\hline 57 & Dermal caudal scutes: $0=$ present; $1=$ absent & Otero \& Gayet, 1996: character 9 \\
\hline 58 & $\begin{array}{l}\text { Overlap of the caudal skeleton by the caudal fin rays: } 0= \\
\text { little overlap; } 1=\text { extensive overlap (hypurostegy) (Fig. 3D, } \\
\text { E) }\end{array}$ & $\begin{array}{l}\text { Le Danois \& Le Danois, 1964; Patterson, } \\
\text { 1968; Oelschläger, } 1974\end{array}$ \\
\hline 59 & $\begin{array}{l}\text { Number of principal rays in the caudal fin: } 0=\text { nineteen or } \\
\text { more; } 1=\text { eighteen or less }\end{array}$ & Otero \& Gayet, 1996: character 11 \\
\hline 60 & Supracleithrum: $0=$ smooth; $1=$ spiny & Otero \& Gayet, 1996: character 34 \\
\hline 61 & $\begin{array}{l}\text { Postcleithra: } 0=\text { separate bones; } 1=\text { two bones fused } \\
\text { together }\end{array}$ & Otero \& Gayet, 1996: character 47 \\
\hline 62 & $\begin{array}{l}\text { Number of autogenous pectoral fin radials: } 0=\text { four; } 1= \\
\text { three }\end{array}$ & Olney et al.,1993: character 7 \\
\hline 63 & $\begin{array}{l}\text { Contact between the pelvic girdle and the coracoid: } 0= \\
\text { absent (Fig. } 4 \mathrm{~A}) ; 1=\text { present (Fig. } 4 \mathrm{~B}, \mathrm{C})\end{array}$ & $\begin{array}{l}\text { Gill, 1903; Le Danois, 1955; Stiassny \& } \\
\text { Moore, 1992: character 5, in part; Otero \& } \\
\text { Gayet, 1996: character 17, in part }\end{array}$ \\
\hline 64 & $\begin{array}{l}\text { Internal wings of the pelvic bone: } 0=\text { separated (Fig. 4D); } 1 \\
=\text { joined medially (Fig. } 4 \mathrm{E}, \mathrm{F} \text { ) }\end{array}$ & New \\
\hline 65 & $\begin{array}{l}\text { Median processes of the pelvic bones: } 0=\text { non-overlapping } \\
\text { (Fig. } 4 \mathrm{E}, \mathrm{F}) ; 1=\text { overlapping medially (Fig. } 4 \mathrm{D})\end{array}$ & Stiassny \& Moore, 1992: character 1, in part \\
\hline 66 & $\begin{array}{l}\text { Number of pelvic soft rays: } 0=\text { eight or more } ; 1=\text { seven; } 2 \\
=\text { six or less }\end{array}$ & $\begin{array}{l}\text { Otero \& Gayet, 1996: characters } 10 \text { and 22; } \\
\text { Alvarado-Ortega \& Than-Marchese, 2012: } \\
\text { character } 10\end{array}$ \\
\hline 67 & Pelvic spine: $0=$ absent; $1=$ present $($ Fig. $4 \mathrm{~B})$ & $\begin{array}{l}\text { Stiassny \& Moore, 1992: character 3; } \\
\text { Johnson \& Patterson, 1993: character } 13\end{array}$ \\
\hline
\end{tabular}


Table 3: Character matrix used in the study.

'†' denotes an extinct taxon; '?' denotes an unknown character state; '-' denotes an unapplicable character state.

\begin{tabular}{|c|c|c|c|c|c|c|c|c|c|c|c|c|c|c|c|c|c|c|c|c|c|c|c|c|c|c|c|c|c|c|c|c|c|c|c|c|c|c|c|c|c|c|c|c|c|c|c|}
\hline & 1 & 2 & 3 & 4 & 5 & 6 & 7 & 8 & 9 & 10 & 11 & 12 & 13 & 14 & 15 & 16 & 17 & 18 & 19 & 20 & 21 & 22 & 23 & 24 & 25 & 26 & 27 & 28 & 29 & 30 & 31 & 32 & 33 & 34 & 35 & 36 & 37 & & 39 & 40 & 41 & 42 & 43 & 44 & 45 & 46 & 47 \\
\hline Synodus & 0 & 0 & 0 & 0 & 0 & 0 & 0 & 0 & 0 & 0 & 0 & 0 & 0 & 0 & 0 & 0 & - & - & - & - & - & 0 & 0 & 0 & 0 & 0 & 1 & 0 & 0 & 0 & 0 & 0 & 0 & 0 & 0 & 0 & 0 & 0 & 0 & 0 & 0 & 0 & 0 & 0 & 0 & 0 & \\
\hline Gymnoscopelus & 0 & 0 & 2 & 0 & 0 & 0 & 0 & 0 & 0 & 1 & 0 & 0 & 0 & 0 & 0 & 0 & - & - & - & - & - & 0 & 0 & 0 & 0 & 1 & 1 & 0 & 0 & 0 & 1 & 0 & 1 & 0 & 0 & 0 & 0 & 0 & 0 & 0 & 0 & 0 & 0 & 0 & 0 & 0 & \\
\hline$\dagger$ Ctenothrissa & 0 & 0 & 0 & 0 & 0 & 0 & 0 & 0 & 0 & 0 & 0 & 0 & 0 & 0 & 0 & 0 & 0 & 0 & 0 & 0 & 0 & ? & 0 & 0 & 1 & 0 & 0 & 0 & 0 & 0 & 0 & 0 & 0 & 0 & ? & ? & 0 & 0 & 0 & 0 & 0 & 0 & 0 & 0 & 0 & 0 & \\
\hline$\dagger P$. numismalis & 0 & 0 & 0 & ? & 1 & 0 & 1 & 0 & 0 & 0 & 0 & 0 & 0 & 0 & 0 & 1 & 0 & 0 & 1 & 0 & 0 & 1 & ? & ? & 1 & 1 & ? & ? & ? & 0 & 0 & 0 & 1 & 0 & 1 & 0 & 0 & 1 & 1 & 2 & 0 & 1 & 1 & 0 & 0 & 1 & \\
\hline$\dagger P$. judensis & 0 & 0 & 0 & 0 & 1 & 0 & 1 & ? & ? & 0 & 0 & 0 & 0 & ? & ? & 1 & 0 & 0 & 1 & 0 & 0 & 1 & ? & ? & 1 & 1 & ? & ? & ? & 0 & 0 & 0 & ? & 0 & 1 & 0 & 0 & 1 & 1 & 2 & 0 & 1 & ? & 0 & 0 & 1 & 1 \\
\hline$\uparrow$ †Aipichthyoides & ? & 0 & 0 & ? & 0 & 1 & 1 & 1 & 0 & 0 & 0 & 0 & 0 & 1 & 1 & 1 & 1 & 1 & 0 & 1 & 0 & 1 & ? & ? & 1 & 1 & 1 & 1 & ? & 0 & 0 & 0 & 1 & 0 & ? & 0 & 0 & 0 & 1 & 1 & 0 & 1 & 1 & 0 & 0 & 1 & \\
\hline$\dagger$ Paraipichthys & 0 & ? & ? & ? & 0 & 0 & ? & ? & 0 & ? & ? & ? & 0 & ? & 0 & 1 & 0 & 0 & 0 & 0 & 0 & ? & ? & ? & 1 & ? & ? & ? & ? & 0 & 0 & 0 & ? & 0 & ? & ? & ? & 0 & 1 & $?$ & ? & 1 & 1 & 0 & 0 & 1 & 1 \\
\hline$\dagger$ Aipichthys velifer & 0 & 0 & 1 & 0 & 0 & 0 & 1 & 1 & 0 & 0 & 0 & 0 & 1 & 1 & 1 & 1 & 0 & 0 & 1 & 0 & 1 & 1 & ? & ? & 1 & 1 & 1 & 1 & 0 & 0 & 0 & 0 & 1 & 0 & 0 & 0 & 0 & 0 & 1 & 1 & 0 & 1 & 1 & 0 & 0 & 1 & \\
\hline$\dagger$ A. oblongus & 0 & ? & ? & ? & 0 & 0 & 1 & ? & 0 & 0 & 0 & 0 & 1 & 1 & 0 & 1 & 0 & 0 & 1 & 0 & 1 & ? & ? & ? & 1 & 1 & ? & ? & ? & 0 & 0 & 0 & 1 & 0 & 0 & 0 & 0 & 0 & 1 & 1 & 0 & 1 & 1 & 0 & 0 & 1 & 1 \\
\hline$\dagger$ †. minor & 0 & 0 & 1 & 0 & 0 & 0 & 1 & 1 & 0 & 0 & 0 & 0 & 1 & 1 & 0 & 1 & 0 & 0 & 1 & 0 & 1 & 1 & ? & ? & 1 & 1 & 1 & 1 & ? & 0 & 0 & 0 & 1 & 0 & 0 & 0 & 0 & 0 & 1 & 1 & 0 & 1 & 1 & 0 & 0 & 1 & \\
\hline$\dagger$ Freigichthys & 0 & 0 & ? & 0 & 0 & 0 & 1 & 1 & 0 & 0 & $?$ & 0 & 1 & 1 & 1 & 1 & 0 & 0 & 1 & 0 & 1 & 1 & ? & ? & 1 & 1 & ? & ? & ? & 0 & 0 & 0 & 1 & 0 & 0 & 0 & 0 & 0 & 1 & 1 & 0 & 1 & 1 & 0 & 0 & 1 & 1 \\
\hline$\dagger$ Aspesaipichthys & 0 & 0 & ? & ? & ? & ? & ? & ? & $?$ & ? & ? & ? & ? & ? & ? & ? & ? & ? & ? & ? & $?$ & ? & ? & ? & 1 & 0 & 1 & ? & ? & 0 & 0 & 0 & 0 & $?$ & ? & ? & ? & 0 & 1 & 1 & 0 & 1 & ? & 0 & 0 & ? & ? \\
\hline †Zoqueichthys & 0 & 0 & 0 & ? & 0 & 0 & 1 & 1 & ? & 0 & 0 & 0 & 0 & ? & ? & 1 & 1 & 0 & 0 & 1 & 0 & 1 & ? & ? & 1 & 1 & ? & 1 & ? & 0 & 0 & 0 & 1 & 0 & 0 & 0 & 0 & 0 & 1 & 1 & 0 & 1 & 1 & 0 & 0 & 1 & 1 \\
\hline$\dagger$ Pycnosteroides & ? & 0 & 0 & 0 & 0 & 0 & 1 & 1 & ? & 0 & 0 & 0 & 0 & 1 & 0 & 1 & 0 & 0 & 1 & 0 & 0 & 1 & ? & ? & 1 & 1 & 0 & 1 & 0 & 0 & 0 & 0 & 1 & 0 & 1 & 0 & 1 & 1 & 0 & 2 & 0 & 1 & 0 & 0 & 0 & 1 & 1 \\
\hline Polymixia & 1 & 0 & 0 & 0 & 0 & 0 & 0 & 0 & 0 & 0 & 0 & 0 & 0 & 1 & 1 & 1 & 0 & 0 & 0 & 0 & 0 & 1 & 1 & 0 & 0 & 1 & 0 & 2 & 0 & 0 & 0 & 0 & 1 & 0 & 1 & 0 & 0 & 0 & 0 & 0 & 0 & 1 & 0 & 0 & 0 & 1 & 1 \\
\hline Merluccius & 2 & 0 & 2 & 0 & 0 & 0 & 1 & 1 & 1 & 1 & 1 & 0 & 0 & 1 & 1 & 1 & 0 & 0 & 0 & 0 & 0 & 1 & 1 & 1 & 1 & 0 & 1 & 2 & 0 & 1 & 1 & 1 & 1 & 1 & 1 & 1 & 1 & 3 & - & 0 & 0 & 0 & 0 & 0 & 0 & 0 & 0 \\
\hline Myripristis & 1 & 0 & 0 & 0 & 0 & 0 & 0 & 0 & 0 & 0 & 0 & 0 & 0 & 1 & 1 & 1 & 0 & 0 & 0 & 0 & 0 & 1 & 1 & 0 & 0 & 0 & 0 & 1 & 0 & 1 & 1 & 0 & 1 & 0 & 1 & 0 & 1 & 1 & 0 & 0 & 0 & 1 & 0 & 0 & 0 & 1 & 1 \\
\hline Metavelifer & 0 & 1 & 2 & 1 & 0 & 1 & 1 & 0 & 0 & 0 & 0 & 1 & 0 & ? & $?$ & 1 & 1 & 0 & 0 & 1 & 0 & 1 & 0 & 0 & 1 & 1 & 0 & 2 & 1 & 0 & 0 & 0 & 1 & 0 & 0 & 1 & 1 & 2 & 1 & 2 & 0 & 1 & 1 & 0 & 0 & 1 & 1 \\
\hline Lampris & 0 & 1 & 2 & 1 & 0 & 1 & 1 & 0 & 0 & 0 & 0 & 1 & 0 & $?$ & $?$ & 1 & 1 & 0 & 0 & 1 & 0 & 1 & 0 & 1 & 1 & 0 & 1 & 2 & 1 & 0 & 0 & 1 & 1 & 0 & - & 1 & 1 & 2 & 1 & 2 & 0 & 0 & 1 & 0 & 0 & 0 & 0 \\
\hline Trachipterus & 0 & 1 & 2 & 1 & 0 & 1 & 1 & 0 & ? & 0 & 0 & 1 & 0 & ? & ? & 0 & - & - & - & - & - & 1 & 0 & 0 & 1 & 0 & 1 & 2 & 1 & 0 & 0 & 2 & 1 & 1 & - & 1 & 1 & 3 & - & 2 & 1 & 0 & 1 & 1 & 1 & - & \\
\hline Regalecus & 0 & 1 & 2 & 1 & 0 & 1 & 1 & 0 & ? & 0 & 0 & 1 & 0 & ? & $?$ & 0 & - & - & - & - & - & 1 & 0 & 0 & \begin{tabular}{|l|}
1 \\
\end{tabular} & 0 & 1 & 2 & 1 & 0 & 0 & 2 & 1 & 1 & - & 1 & 1 & 3 & - & 2 & 1 & 0 & 1 & 1 & 1 & - & \\
\hline
\end{tabular}


Table 3 (continued):

\begin{tabular}{|c|c|c|c|c|c|c|c|c|c|c|c|c|c|c|c|c|c|c|c|c|}
\hline & 48 & 49 & 50 & 51 & 52 & 53 & 54 & 55 & 56 & 57 & 58 & 59 & 60 & 61 & 62 & 63 & 64 & 65 & 66 & 67 \\
\hline Synodus & 0 & 0 & 0 & 0 & 0 & 0 & 0 & 0 & $?$ & 0 & 0 & 0 & 0 & 0 & 0 & 0 & 0 & 0 & 0 & 0 \\
\hline Gymnoscopelus & 0 & 1 & 0 & 0 & 0 & 0 & 0 & 0 & 0 & 0 & 1 & 0 & 0 & 0 & 0 & 0 & 0 & 0 & 0 & 0 \\
\hline$\dagger$ Ctenothrissa & 0 & 0 & 0 & 0 & 0 & 0 & 0 & 0 & 0 & 0 & 0 & 0 & 0 & $?$ & 0 & 1 & $?$ & $?$ & 0 & 0 \\
\hline$\dagger$ Pharmacichthys venenifer & 0 & 1 & 0 & 0 & 0 & 0 & 0 & 0 & 0 & 1 & 1 & 0 & 0 & 0 & 0 & 1 & $?$ & $?$ & 2 & 0 \\
\hline$\dagger P$. numismalis & 0 & 1 & 0 & 0 & 0 & 0 & 0 & 0 & 0 & 1 & 1 & 0 & 0 & 0 & 0 & 1 & $?$ & $?$ & 2 & 0 \\
\hline$\dagger P$. judensis & 0 & 1 & 0 & 0 & 0 & 0 & 0 & 0 & $?$ & 1 & 1 & 0 & 0 & 0 & $?$ & 1 & $?$ & $?$ & 2 & 0 \\
\hline$\uparrow$ Aipichthyoides & 0 & 0 & 1 & 1 & 0 & 0 & 1 & 1 & 1 & 1 & 1 & 0 & 0 & 0 & 0 & 1 & $?$ & $?$ & 1 & 0 \\
\hline$\dagger$ Paraipichthys & 0 & 0 & 0 & 0 & 0 & 0 & 0 & 0 & 1 & 1 & 1 & 0 & $?$ & 0 & 0 & 1 & $?$ & $?$ & 2 & 0 \\
\hline$\dagger$ Aipichthys velifer & 0 & 0 & 0 & 0 & 0 & 0 & 0 & 0 & 1 & 1 & 1 & 0 & 0 & 0 & 0 & 1 & $?$ & $?$ & 2 & 0 \\
\hline$\dagger A$. oblongus & 0 & 0 & 0 & 0 & 0 & 0 & 0 & 0 & 1 & 1 & 1 & $?$ & 0 & 0 & 0 & 1 & $?$ & $?$ & $?$ & 0 \\
\hline$\dagger$ A. minor & 0 & 0 & 0 & 0 & 0 & 0 & 0 & 0 & 1 & 1 & 1 & 0 & 0 & 0 & 0 & 1 & $?$ & $?$ & 2 & 0 \\
\hline$\dagger$ Freigichthys & 0 & 0 & 0 & $?$ & $?$ & 0 & $?$ & 0 & 1 & 1 & 1 & $?$ & 0 & 0 & 0 & 1 & 1 & 0 & 1 & 0 \\
\hline$\dagger$ Aspesaipichthys & 0 & 0 & 0 & 1 & 1 & 0 & 1 & 1 & 1 & 1 & 1 & 0 & $?$ & $?$ & $?$ & $?$ & $?$ & $?$ & $?$ & ? \\
\hline$†$ Zoqueichthys & 0 & 0 & 0 & 0 & 0 & 0 & 0 & 0 & 1 & 1 & 1 & 0 & 0 & 0 & 0 & 1 & 1 & 0 & 0 & 0 \\
\hline$\dagger$ Pycnosteroides & 1 & 0 & 0 & 0 & 0 & 0 & 0 & 0 & 1 & 1 & 1 & 1 & 0 & 0 & 0 & 1 & $?$ & $?$ & 2 & 1 \\
\hline Polymixia & 1 & 0 & 0 & 0 & 0 & 0 & 0 & 0 & 1 & 1 & 0 & 1 & 0 & 0 & 0 & 0 & 0 & 1 & 1 & 0 \\
\hline$\dagger$ †phenocephalus & 1 & 0 & 1 & 0 & 0 & 0 & 0 & 0 & 1 & 1 & 0 & 1 & 1 & 0 & 0 & 0 & 0 & 1 & 1 & ? \\
\hline Aphredoderus & 1 & 0 & 1 & 0 & 1 & 1 & 1 & 0 & 1 & 1 & 0 & 1 & 1 & 1 & 0 & 0 & 0 & 1 & 1 & 0 \\
\hline Merluccius & 1 & 1 & 1 & 1 & 1 & 1 & 1 & 0 & 1 & 1 & 0 & 1 & 1 & 1 & 0 & 0 & 0 & 0 & 1 & 0 \\
\hline Myripristis & 0 & 0 & 0 & 1 & 0 & 0 & 0 & 0 & 1 & 1 & 0 & 0 & 1 & 0 & 0 & 1 & 1 & 0 & 1 & 1 \\
\hline Metavelifer & 0 & 0 & 0 & 0 & 1 & 1 & 1 & 0 & 1 & 1 & 1 & 0 & 0 & 1 & 0 & 1 & 1 & 0 & 0 & 0 \\
\hline Lampris & 0 & 0 & 1 & 1 & 1 & 1 & 1 & 0 & 1 & 1 & 1 & 0 & 0 & 1 & 1 & 1 & 1 & 0 & 0 & 0 \\
\hline Trachipterus & 1 & 0 & 1 & 1 & 1 & 0 & 1 & 0 & 1 & 1 & 0 & 1 & 0 & 1 & 1 & 1 & 1 & 0 & 2 & 0 \\
\hline Regalecus & - & - & - & 1 & - & - & - & 0 & 1 & 1 & 0 & 1 & 0 & 1 & 1 & 1 & 1 & 0 & 2 & 0 \\
\hline
\end{tabular}




\section{FIGURE LEGENDS}
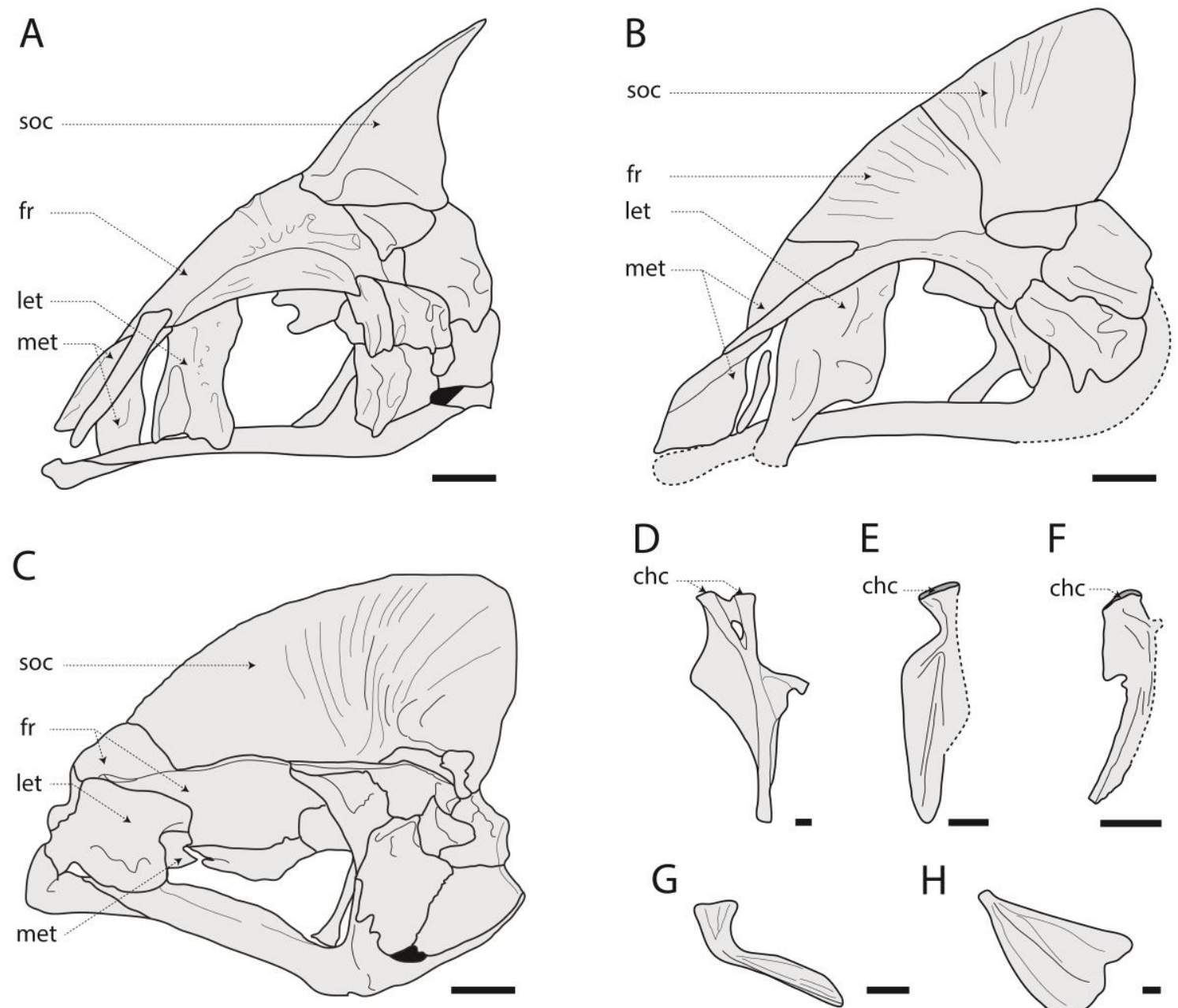

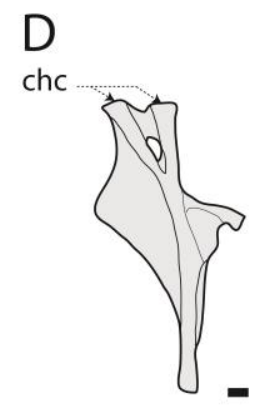

G

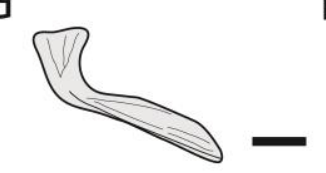

$\mathrm{E}$

$\mathrm{F}$

chc

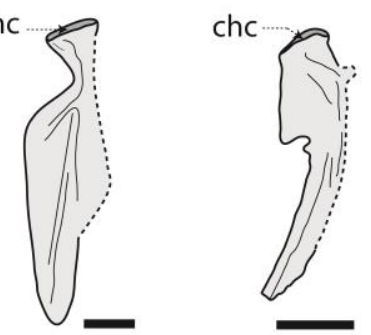

$\mathrm{H}$

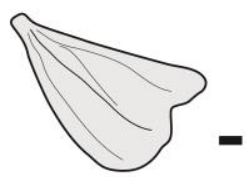

Figure 1. Cranial skeleton of several taxa studied. A, neurocranium of $\uparrow$ Aipichthys velifer (reconstruction), after Gayet (1980a: fig. 25). Scale bar: $2 \mathrm{~mm}$. B, neurocranium of $\dagger$ Aipichthyoides galeatus (reconstruction), after Gayet (1980b: fig. 8). Scale bar: 3 mm. C, neurocranium of Lampris guttatus, after Oelschläger (1983: Fig. 12). Scale bar: $2 \mathrm{~cm}$. D, left hyomandibula of the myctophiform Lampanyctus sp., after Paxton (1972: fig. 7B). Scale bar: $1 \mathrm{~mm}$. E, left hyomandibula of $\dagger$ Aipichthys minor, after Otero \& Gayet (1996: fig. 8A). Scale bar: $1 \mathrm{~mm}$. F, left hyomandibula of Metavelifer multiradiatus, AMNH 91808SD. Scale bar: 1 cm. G, urohyal of Merluccius, MNHN research collection. Scale bar: $1 \mathrm{~cm}$. H, urohyal of Lampris guttatus, AMNH 79669SD. Scale bar: $1 \mathrm{~cm}$. Abbreviations: chc, craniohyomandibular condyle; fr, frontal; let, lateral ethmoid; met, mesethmoid; soc, supraoccipital. 

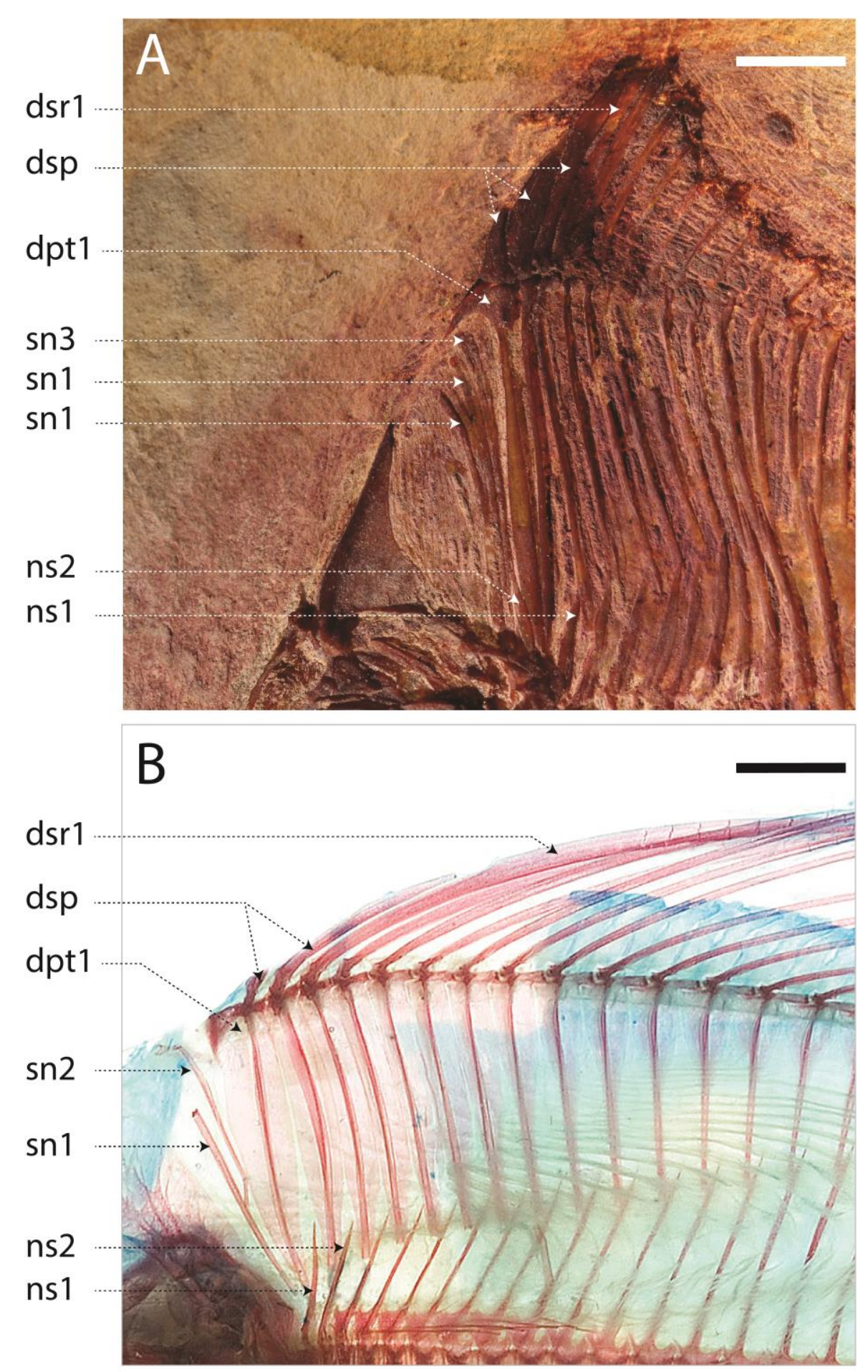

Figure 2. Dorsal fin skeleton of two studied taxa. A, †Aipichthys velifer, MNHN.F.HAK57. Scale bar: $1 \mathrm{~cm}$. Photo D. Davesne. B, Velifer hypselopterus (Veliferidae), AMS 21840020. Scale bar: $5 \mathrm{~mm}$. Photo courtesy D. Johnson. Abbreviations: dpt, dorsal pterygiophore; dsp, dorsal spine; dsr, dorsal soft ray; ns, neural spine; sn, supraneural. 
A

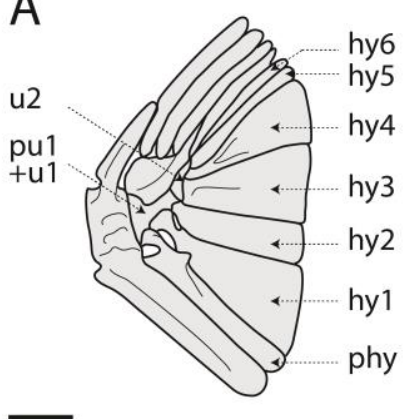

B

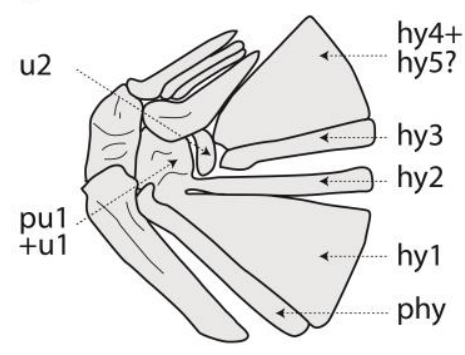

C

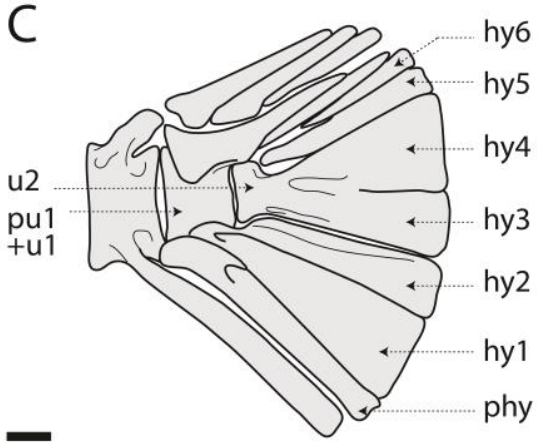

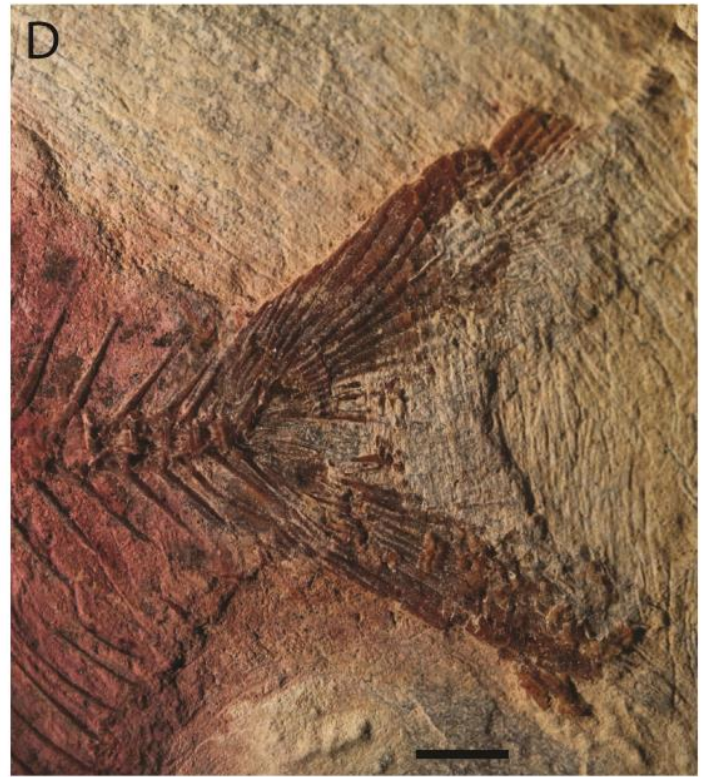

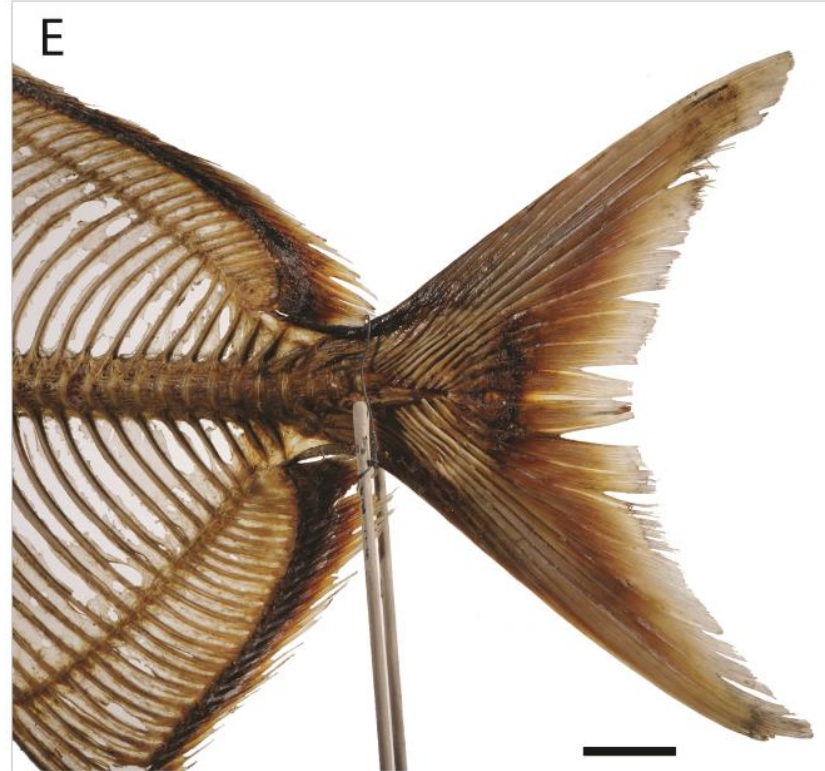

Figure 3. Caudal skeleton of several studied taxa. A, $\uparrow$ Aipichthys minor (reconstruction), after Patterson (1968: fig. 11A). Scale bar: $1 \mathrm{~mm}$. B, $\uparrow$ Aspesaipichthys cavaensis (reconstruction), after Taverne (2004: fig. 7). Scale bar: $1 \mathrm{~mm}$. C, Velifer hypselopterus (=V. africanus) (Veliferidae), after Oelschläger (1983: Fig. 82). Scale bar: $1 \mathrm{~mm} . \mathrm{D}, \uparrow$ Aipichthys velifer, MNHN.F.HAK57, showing hypurostegy of the caudal fin rays. Scale bar: $5 \mathrm{~mm}$. Photo D. Davesne. E, Lampris guttatus, ZMUC 74, showing hypurostegy of the caudal fin rays. Scale bar: $5 \mathrm{~cm}$. Photo M.A. Krag. Abbreviations: hy, hypural; phy, parhypural; pu, preural vertebral centrum; $u$, ural vertebral centrum. 

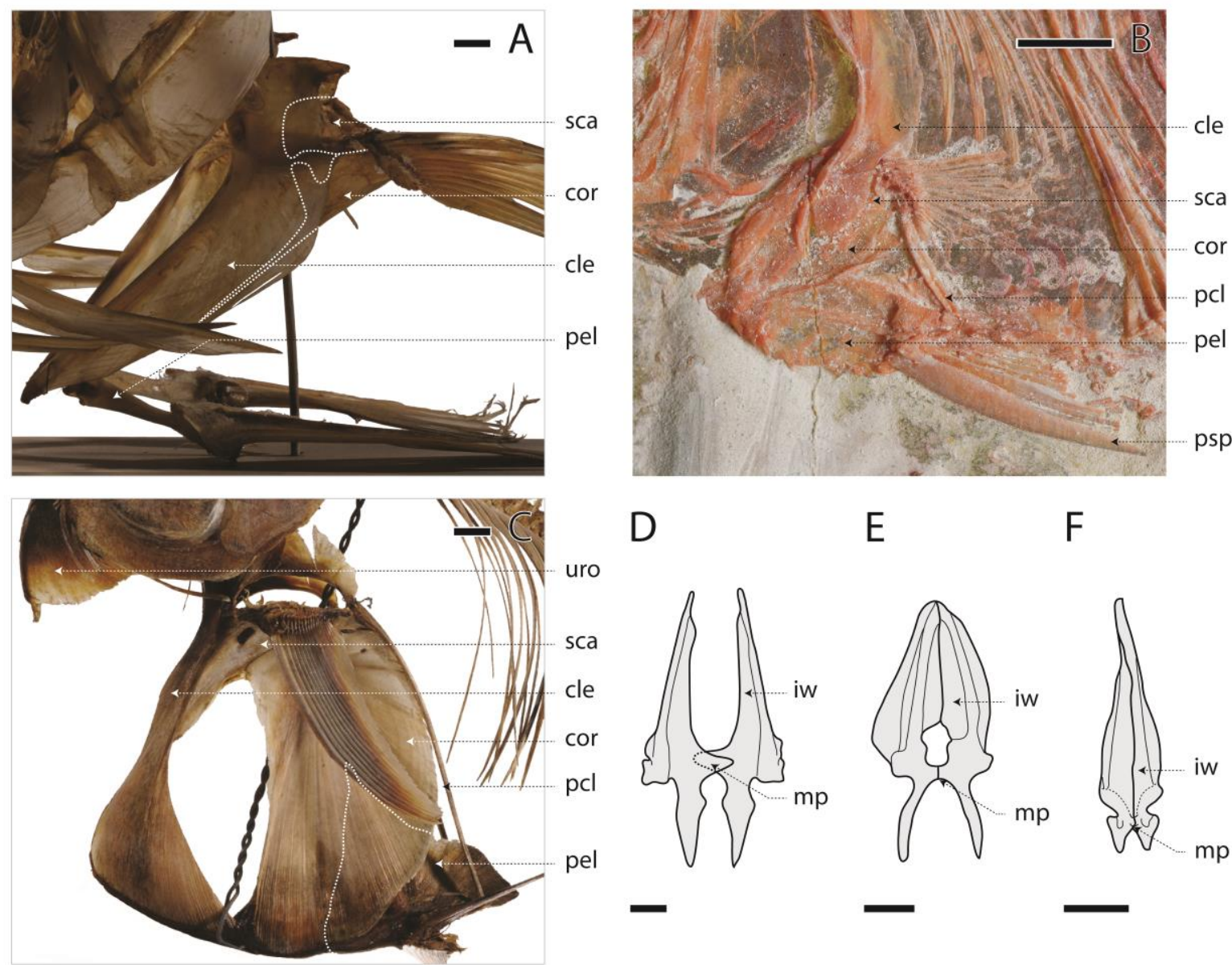

D

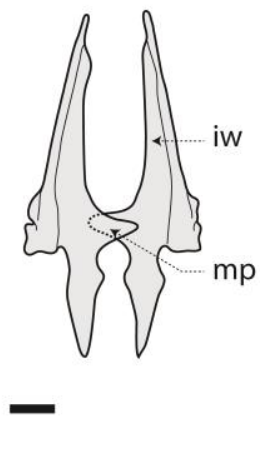

$E$

$\mathrm{F}$
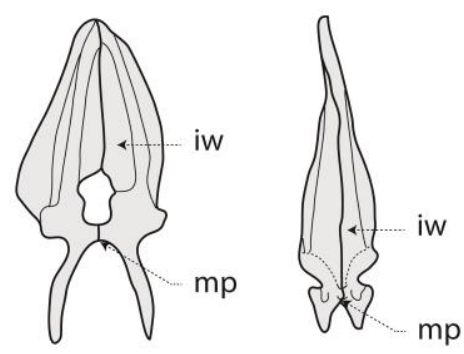

Figure 4. Appendicular skeleton of several studied taxa. A, pectoral and pelvic girdles of Merluccius merluccius, ZMUC 215x, with shapes of scapula and coracoid outlined. Scale bar: $2 \mathrm{~cm}$. Photo M.A. Krag. B, pectoral and pelvic girdles of $\uparrow$ Pycnosteroides levispinosus, MNHN.F.HDJ105. Scale bar: $5 \mathrm{~mm}$. Photo D. Davesne. C, pectoral and pelvic girdles of Lampris guttatus, ZMUC 74, with shape of the pelvic girdle outlined. Scale bar: $5 \mathrm{~cm}$. Photo M.A. Krag. D, pelvic girdle of Polymixia sp. in ventral view, after Stiassny \& Moore (1992: fig. 3). Scale bar: $2 \mathrm{~mm}$. E, pelvic girdle of $\dagger$ Zoqueichthys carolinae in ventral view, after Alvarado-Ortega \& Than-Marchese (2012: fig. 5). Scale bar: $1 \mathrm{~mm}$. F, pelvic girdle of Metavelifer multiradiatus, AMNH 91800SD, in ventral view. Scale bar: $2 \mathrm{~mm}$.

Abbreviations: cle, cleithrum; cor, coracoid; iw, internal wing of the pelvic girdle; $\mathrm{mp}$, median process of the pelvic girdle; pcl, postcleithrum; pel, pelvic girdle; psp, pelvic spine; sca, scapula; uro, urohyal. 


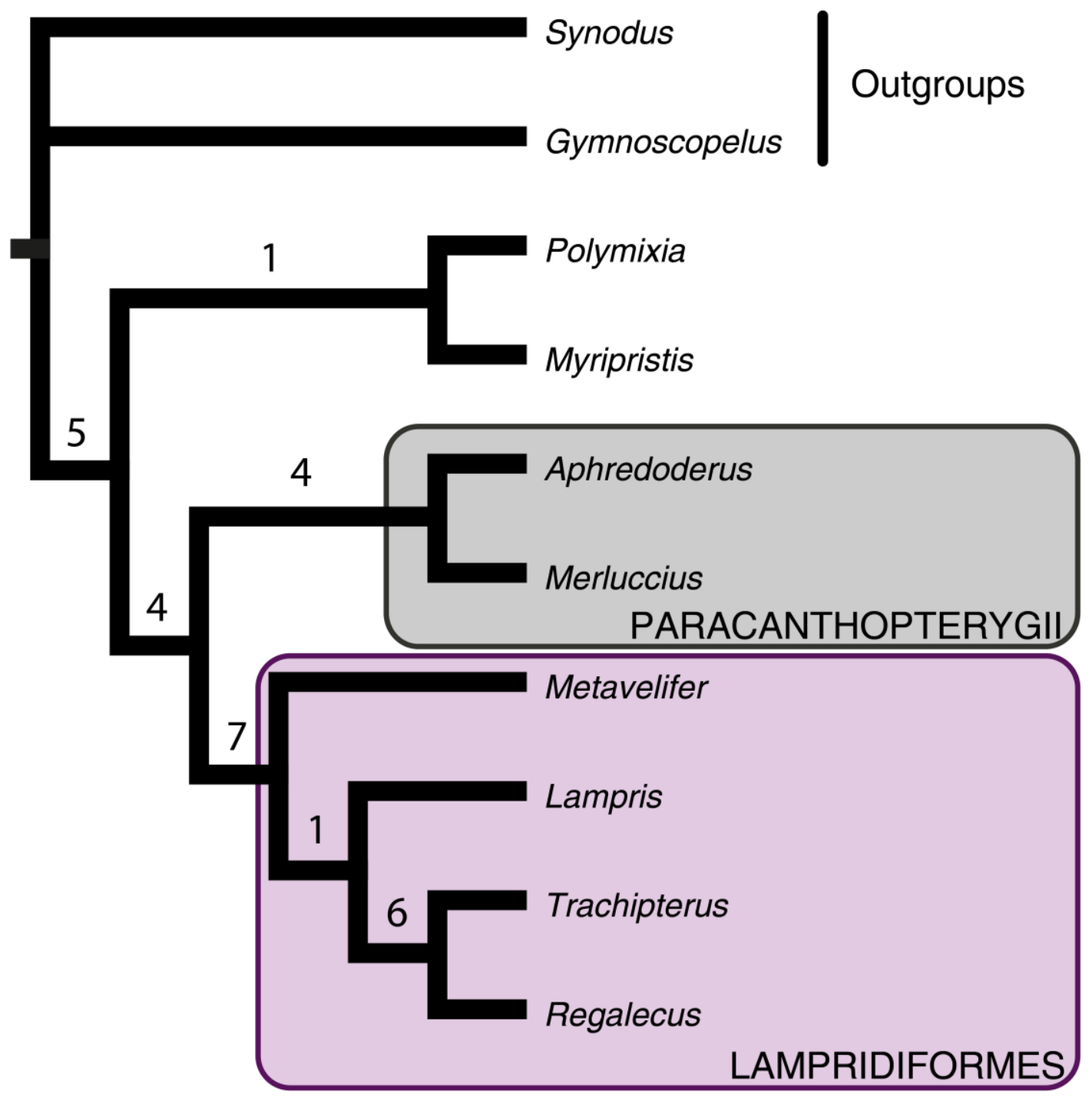

Figure 5. Most parsimonious tree obtained after analysis 1 (only the ten extant taxa included). Numbers above branches are Bremer indexes. Length $=107, \mathrm{CI}=0.64, \mathrm{RI}=0.71$. 


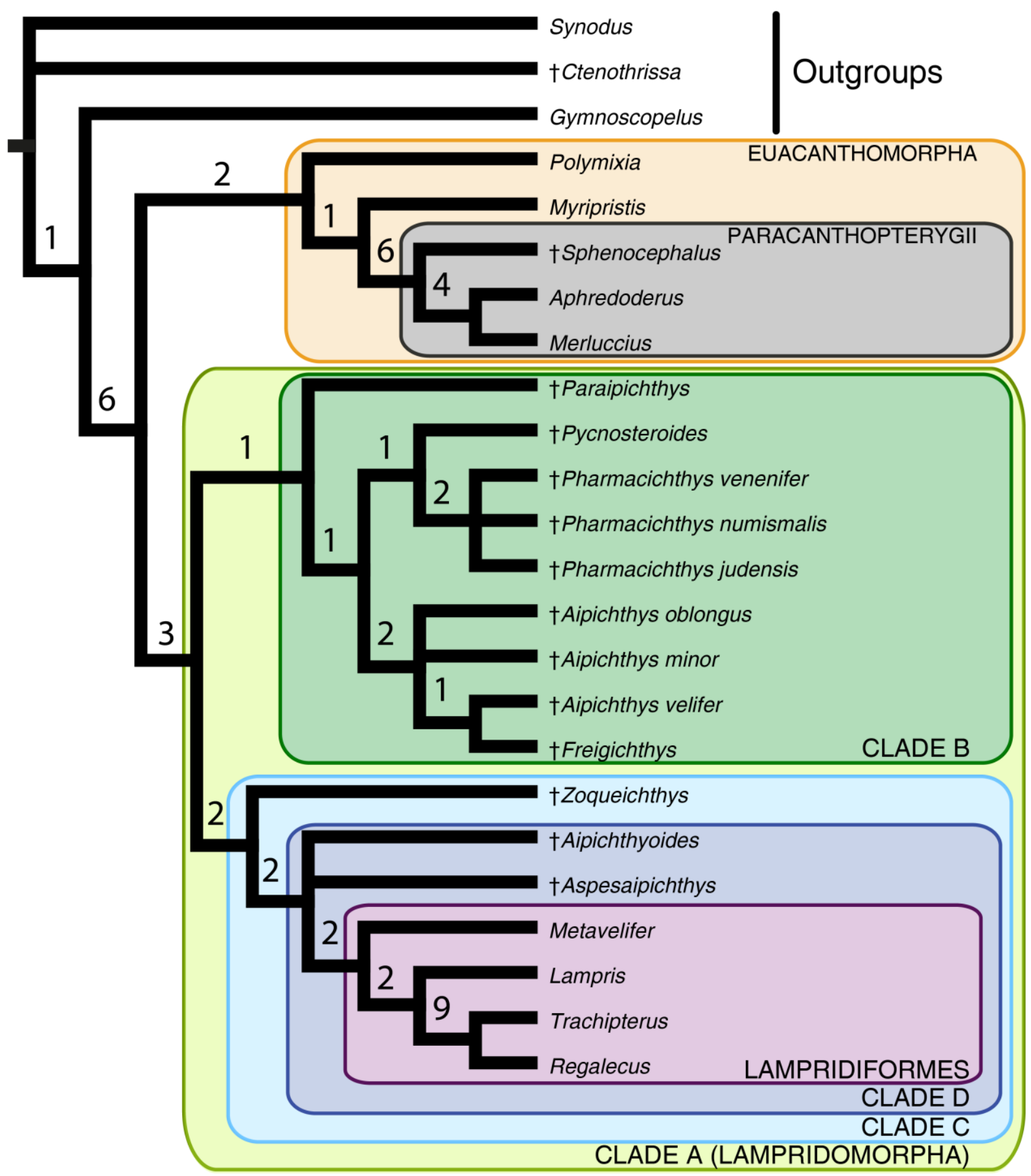

Figure 6. Strict consensus of the 12 most parsimonious trees obtained after analysis 2 (all 24 taxa, fossil and extant, included). Fossil taxa are indicated by daggers $(\dagger)$. Numbers above branches are Bremer indexes. Length $=155, \mathrm{CI}=0.48, \mathrm{RI}=0.72$. 


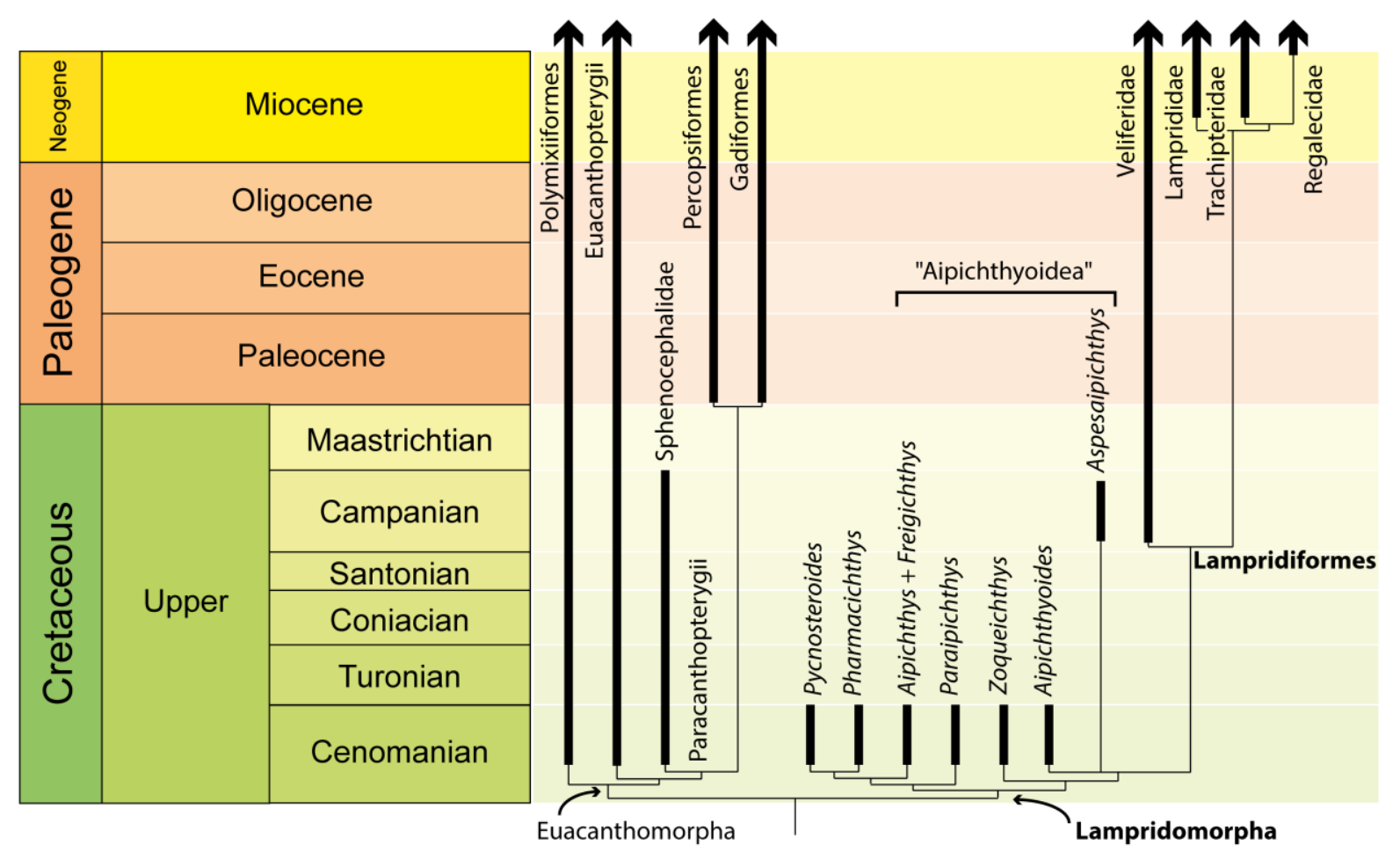

Figure 7. Hypothesis of acanthomorph interrelationships suggested by our results, with ages of taxa highlighted (thick lines). Position of internal nodes does not reflect divergence times. 


\section{APPENDIX}

\section{COMPLETE LIST OF CHARACTER STATE CHANGES}

Character state changes in italics are ambiguous optimizations that we chose based on biological considerations. Character state changes in bold are unique to the clade (with no homoplasy outside the clade).

Analysis 1 (ten taxa, all extant):

Synodus autapomorphy: $33(\mathbf{1} \rightarrow \mathbf{0})$

Gymnoscopelus autapomorphies: $3(0 \rightarrow 2) ; 10(0 \rightarrow 1) ; 26(0 \rightarrow 1) ; 31(0 \rightarrow 1) ; 49(0 \rightarrow 1) ; 58$ $(0 \rightarrow 1)$

Acanthomorpha: $14(0 \rightarrow 1) ; 15(0 \rightarrow 1) ; 16(0 \rightarrow 1) ; 22(0 \rightarrow 1) ; 28(0 \rightarrow 2) ; 42(0 \rightarrow 1) ; 46$ $(0 \rightarrow 1) ; 47(0 \rightarrow 1) ; 56(0 \rightarrow 1) ; 57(\mathbf{0 \rightarrow 1})$

Polymixia + Myripristis: $1(\mathbf{0 \rightarrow 1}) ; 23(0 \rightarrow 1) ; 27(1 \rightarrow 0) ; 35(0 \rightarrow 1) ; 66(0 \rightarrow 1)$

Polymixia autapomorphies: $26(0 \rightarrow 1) ; 48(0 \rightarrow 1) ; 59(0 \rightarrow 1) ; 65(0 \rightarrow 1)$

Myripristis autapomorphies: $28(\mathbf{2} \rightarrow \mathbf{1}) ; 30(0 \rightarrow 1) ; 31(0 \rightarrow 1) ; 37(0 \rightarrow 1) ; 38(\mathbf{0 \rightarrow 1}) ; 51$

$(0 \rightarrow 1) ; 60(0 \rightarrow 1) ; 63(0 \rightarrow 1) ; 64(0 \rightarrow 1) ; 67(0 \rightarrow 1)$

Paracanthopterygii + Lampridiformes: $3(0 \rightarrow 2) ; 7(\mathbf{0 \rightarrow 1}) ; 36(\mathbf{0 \rightarrow 1}) ; 37(0 \rightarrow 1) ; 38(\mathbf{0 \rightarrow 2}) ; 52$ $(0 \rightarrow 1) ; 53(0 \rightarrow 1) ; 54(0 \rightarrow 1) ; 61(0 \rightarrow 1)$

Aphredoderus + Merluccius (= extant Paracanthopterygii): $8(\mathbf{0} \rightarrow \mathbf{1}) ; \mathbf{9}(\mathbf{0} \rightarrow \mathbf{1}) ; 10(0 \rightarrow 1) ; \mathbf{1 1}$

$(0 \rightarrow 1) ; 23(0 \rightarrow 1) ; 30(0 \rightarrow 1) ; 31(0 \rightarrow 1) ; 34(0 \rightarrow 1) ; 35(0 \rightarrow 1) ; 48(0 \rightarrow 1) ; 50(0 \rightarrow 1) ; 59$

$(0 \rightarrow 1) ; 60(0 \rightarrow 1) ; 66(0 \rightarrow 1)$

Aphredoderus autapomorphies: $19(0 \rightarrow 1) ; 65(0 \rightarrow 1)$

Merluccius autapomorphies: $1(\mathbf{0 \rightarrow 2}) ; 24(0 \rightarrow 1) ; 25(0 \rightarrow 1) ; 32(0 \rightarrow 1) ; 38(2 \rightarrow 3) ; 42(1 \rightarrow 0)$; $46(1 \rightarrow 0) ; 47(1 \rightarrow 0) ; 49(0 \rightarrow 1) ; 51(0 \rightarrow 1)$

Lampridiformes: $2(0 \rightarrow 1) ; 4(0 \rightarrow 1) ; 6(0 \rightarrow 1) ; 12(0 \rightarrow 1) ; 17(0 \rightarrow 1) ; 20(0 \rightarrow 1) ; 25(0 \rightarrow 1) ; 29$ $(\mathbf{0 \rightarrow 1}) ; 39(\mathbf{0 \rightarrow 1}) 40(\mathbf{0 \rightarrow 2}) ; 43(\mathbf{0 \rightarrow 1}) ; 58(0 \rightarrow 1) ; 63(0 \rightarrow 1) ; 64(0 \rightarrow 1)$

Metavelifer autapomorphies: $26(0 \rightarrow 1) ; 27(1 \rightarrow 0)$

Lampris + Trachipterus + Regalecus: $32(0 \rightarrow 1) ; 42(1 \rightarrow 0) ; 46(1 \rightarrow 0) ; 47(1 \rightarrow 0) ; 50(0 \rightarrow 1)$;

$51(0 \rightarrow 1) ; 62(\mathbf{0} \rightarrow \mathbf{1})$

Lampris autapomorphy: $24(0 \rightarrow 1)$

Trachipterus + Regalecus $(=$ Taeniosomi): $16(1 \rightarrow 0) ; 32(1 \rightarrow 2) ; 34(0 \rightarrow 1) ; 38(2 \rightarrow 3) ; 41$

$(0 \rightarrow 1) ; 44(0 \rightarrow 1) ; 45(0 \rightarrow 1) ; 58(\mathbf{1} \rightarrow \mathbf{0}) ; 59(0 \rightarrow 1) ; 66(0 \rightarrow 2)$

Trachipterus autapomorphies: $48(0 \rightarrow 1) ; 53(1 \rightarrow 0)$

Regalecus autapomorphies: none

Analysis 2 (24 taxa, extant and fossils):

Remark: The topology presented here is a strict consensus of 12 parsimonious trees, resulting in polytomies. We chose to present "hard" polytomies, where character states are assumed to have appeared independently from other branches in the polytomy. One should remember, however, that this topology does not always reflect the most parsimonious interpretation possible.

Synodus autapomorphies: none 
$\dagger$ Ctenothrissa autapomorphies: $25(0 \rightarrow 1) ; 27(1 \rightarrow 0) ; 63(0 \rightarrow 1)$

Gymnoscopelus + Acanthomorpha (= Ctenosquamata): $26(\mathbf{0} \rightarrow \mathbf{1}) ; 33(\mathbf{0} \rightarrow \mathbf{1})$

Gymnoscopelus autapomorphies: $3(0 \rightarrow 2) ; 10(0 \rightarrow 1) ; 31(0 \rightarrow 1) ; 49(0 \rightarrow 1) ; 58(0 \rightarrow 1)$

Acanthomorpha: $14(0 \rightarrow 1) ; 16(0 \rightarrow 1) ; 22(0 \rightarrow 1) ; 28(0 \rightarrow 1) ; 42(0 \rightarrow 1) ; 46(0 \rightarrow 1) ; 47$

$(0 \rightarrow 1) ; 56(0 \rightarrow 1) ; 57(0 \rightarrow 1)$

Euacanthomorpha: $1(\mathbf{0 \rightarrow 1}) ; 15(0 \rightarrow 1) ; 23(\mathbf{0 \rightarrow 1}) ; 27(1 \rightarrow 0) ; 35(0 \rightarrow 1) ; 66(0 \rightarrow 1)$

Polymixia autapomorphies: $28(1 \rightarrow 2) ; 48(0 \rightarrow 1) ; 59(0 \rightarrow 1) ; 65(0 \rightarrow 1)$;

Myripristis + Paracanthopterygii: $26(1 \rightarrow 0) ; 30(\mathbf{0 \rightarrow 1}) ; 31(0 \rightarrow 1) ; 37(0 \rightarrow 1) ; 6 \mathbf{0 0}(\mathbf{0 \rightarrow 1})$

Myripristis autapomorphies: $38(0 \rightarrow 1) ; 51(0 \rightarrow 1) ; 63(0 \rightarrow 1) ; 64(0 \rightarrow 1) ; 65(1 \rightarrow 0) ; 67(0 \rightarrow 1)$

Paracanthopterygii: $1(\mathbf{1 \rightarrow 2}) ; 3(0 \rightarrow 1) ; 8(0 \rightarrow 1) ; 10(0 \rightarrow 1) ; 11(\mathbf{0 \rightarrow 1}) ; 28(1 \rightarrow 2) ; 34(0 \rightarrow 1)$; $38(0 \rightarrow 2) ; 48(0 \rightarrow 1) ; 50(0 \rightarrow 1) ; 59(0 \rightarrow 1)$

$\dagger$ Sphenocephalus autapomorphies: $19(0 \rightarrow 1) ; 25(0 \rightarrow 1) ; 65(0 \rightarrow 1)$

Aphredoderus + Merluccius: $3(1 \rightarrow 2) ; 7(0 \rightarrow 1) ; 9(0 \rightarrow 1) ; 27(0 \rightarrow 1) ; 36(0 \rightarrow 1) ; 52(0 \rightarrow 1)$;

$53(0 \rightarrow 1) ; 54(0 \rightarrow 1) ; 61(0 \rightarrow 1)$

Aphredoderus autapomorphies: $1(2 \rightarrow 0) ; 19(0 \rightarrow 1) ; 65(0 \rightarrow 1)$

Merluccius autapomorphies: $24(0 \rightarrow 1) ; 25(0 \rightarrow 1) ; 32(0 \rightarrow 1) ; 38(2 \rightarrow 3) ; 42(1 \rightarrow 0) ; 46$

$(1 \rightarrow 0) ; 47(1 \rightarrow 0) ; 49(0 \rightarrow 1) ; 51(0 \rightarrow 1)$

Clade A (=Lampridomorpha): $7(0 \rightarrow 1) ; 8(0 \rightarrow 1) ; 25(0 \rightarrow 1) ; 39(\mathbf{0} \rightarrow \mathbf{1}) ; 40(\mathbf{0} \rightarrow \mathbf{1}) ; 43(\mathbf{0 \rightarrow 1})$; $58(0 \rightarrow 1) ; 63(0 \rightarrow 1) ; 64(0 \rightarrow 1)$

Clade B: $66(0 \rightarrow 2)$

$\uparrow$ Paraipichthys autapomorphies: none

$\uparrow$ Pycnosteroides $+\uparrow$ Pharmacichthys $+\dagger "$ Aipichthys" $+\dagger$ Freigichthys: $19(0 \rightarrow 1)$

$\dagger$ Pycnosteroides $+\uparrow$ Pharmacichthys: $27(1 \rightarrow 0) ; 35(0 \rightarrow 1) ; 38(0 \rightarrow 1) ; 40(1 \rightarrow 2)$

$\dagger$ Pycnosteroides autapomorphies: $37(0 \rightarrow 1) ; 39(1 \rightarrow 0) ; 43(1 \rightarrow 0) ; 48(0 \rightarrow 1) ; 59(0 \rightarrow 1) ; 67$

$(0 \rightarrow 1)$

$\dagger$ Pharmacichthys: $5(\mathbf{0 \rightarrow 1}) ; 8(1 \rightarrow 0) ; 49(0 \rightarrow 1) ; 56(1 \rightarrow 0)$

$\dagger P$. venenifer autapomorphy: $40(2 \rightarrow 1)$

$\dagger P$. numismalis autapomorphy: $14(1 \rightarrow 0)$

$\dagger P$. judensis autapomorphies: none

†"Aipichthys" + †Freigichthys: $3(0 \rightarrow 1) ; 13(\mathbf{0 \rightarrow 1}) ; 21(\mathbf{0 \rightarrow 1})$

$\dagger$ A. oblongus autapomorphies: none

$\uparrow A$. minor autapomorphies: none

$\dagger$ A. velifer $+\dagger$ Freigichthys: $15(0 \rightarrow 1)$

$\uparrow$. velifer autapomorphies: none

$\uparrow$ Freigichthys autapomorphy: $66(2 \rightarrow 1)$

Clade C: $17(\mathbf{0} \rightarrow \mathbf{1}) ; 20(\mathbf{0} \rightarrow \mathbf{1})$

$\dagger$ Zoqueichthys autapomorphies: none

Clade D: $6(\mathbf{0 \rightarrow 1}) ; 51(0 \rightarrow 1) ; 54(0 \rightarrow 1)$

$\uparrow$ Aipichthyoides autapomorphies: $15(0 \rightarrow 1) ; 18(\mathbf{0 \rightarrow 1}) ; 50(0 \rightarrow 1) ; 55(0 \rightarrow 1) ; 66(0 \rightarrow 1)$

$\dagger$ Aspesaipichthys autapomorphies: $26(1 \rightarrow 0) ; 33(1 \rightarrow 0) ; 52(0 \rightarrow 1) ; 55(0 \rightarrow 1)$

Lampridiformes: $\mathbf{2}(\mathbf{0 \rightarrow 1}) ; 3(0 \rightarrow 2) ; \mathbf{4}(\mathbf{0} \rightarrow \mathbf{1}) ; 8(1 \rightarrow 0) ; 12(\mathbf{0 \rightarrow 1}) ; 28(1 \rightarrow 2) ; 29(\mathbf{0} \rightarrow \mathbf{1}) ; 36$

$(0 \rightarrow 1) ; 37(0 \rightarrow 1) ; 38(0 \rightarrow 2) ; 40(1 \rightarrow 2) ; 52(0 \rightarrow 1) ; 53(0 \rightarrow 1) ; 61(0 \rightarrow 1)$

Metavelifer autapomorphies: $27(1 \rightarrow 0) ; 51(1 \rightarrow 0)$ 
Lampris + Trachipterus + Regalecus: $26(1 \rightarrow 0) ; 32(0 \rightarrow 1) ; 42(1 \rightarrow 0) ; 46(1 \rightarrow 0) ; 47(1 \rightarrow 0)$; $50(0 \rightarrow 1) ; 62(\mathbf{0} \rightarrow \mathbf{1})$

Lampris autapomorphy: $24(0 \rightarrow 1)$

Trachipterus + Regalecus $(=$ Taeniosomi): $16(\mathbf{1} \rightarrow \mathbf{0}) ; 32(\mathbf{1 \rightarrow 2}) ; 34(0 \rightarrow 1) ; 38(2 \rightarrow 3) ; 41$

$(\mathbf{0 \rightarrow 1}) ; 44(\mathbf{0 \rightarrow 1}) ; 45(\mathbf{0 \rightarrow 1}) ; 58(\mathbf{1 \rightarrow 0}) ; 59(0 \rightarrow 1) ; 66(0 \rightarrow 2)$

Trachipterus autapomorphies: $48(0 \rightarrow 1) ; 53(1 \rightarrow 0)$

Regalecus autapomorphies: none 